WORKING PAPER 203

Why Are Banks Not Recapitalized During Crises? 
The Working Paper series of the Oesterreichische Nationalbank is designed to disseminate and to provide a platform for discussion of either work of the staff of the OeNB economists or outside contributors on topics which are of special interest to the OeNB. To ensure the high quality of their content, the contributions are subjected to an international refereeing process. The opinions are strictly those of the authors and do in no way commit the OeNB.

The Working Papers are also available on our website (http://www.oenb.at) and they are indexed in RePEc (http://repec.org/).

Publisher and editor

Editorial Board

of the Working Papers

\section{Coordinating editor}

Design

DVR 0031577

ISSN 2310-5321 (Print)

ISSN 2310-533X (Online)

(C) Oesterreichische Nationalbank, 2015. All rights reserved.

Oesterreichische Nationalbank

Otto-Wagner-Platz 3, 1090 Vienna, Austria

PO Box 61, 1011 Vienna, Austria

www.oenb.at

oenb.info@oenb.at

Phone (+43-1) 40420-6666

Fax (+43-1) 40420-046698

Doris Ritzberger-Grünwald, Ernest Gnan, Martin Summer

Martin Summer

Communications and Publications Division 


\section{Editorial}

On the occasion of the 65th birthday of Governor Klaus Liebscher and in recognition of his commitment to Austria's participation in European monetary union and to the cause of European integration, the Oesterreichische Nationalbank (OeNB) established a "Klaus Liebscher Award". It has been offered annually since 2005 for up to two excellent scientific papers on European monetary union and European integration issues. The authors must be less than 35 years old and be citizens from EU member or EU candidate countries. Each "Klaus Liebscher Award" is worth EUR 10,000. The winning papers of the eleventh Award 2015 were written by Matteo Crosignani and Anil Ari. Matteo Crosignani's paper is presented in this Working Paper while Anil Ari's contribution is contained in Working Paper 202.

June 15, 2015 



\title{
Why Are Banks Not Recapitalized During Crises?*
}

\author{
Matteo Crosignani ${ }^{\dagger}$ \\ NYU Stern \\ This Draft: May 2015 \\ First Draft: September 2013
}

\begin{abstract}
I develop a model where governments might prefer to have an undercapitalized domestic financial sector during crises. Weak banks optimally tilt their sovereign bond portfolio towards domestic securities that are positively correlated with banks' other sources of revenues. Governments anticipate this gambling-forresurrection motive and therefore face a trade-off when setting capital regulation. Undercapitalized banks act as buyers of last resort for home public debt at the cost of crowding-out private lending. Following recapitalizations, governments may face lower debt capacity and higher sovereign yields. European stress test data support the proposed mechanism as high leverage banks increased domestic government bond holdings relative to low leverage banks during the crisis. The general equilibrium model can rationalize, in the context of the Eurozone periphery, the increased banks' holdings of domestic public debt, the decreasing private lending, and the prolonged undercapitalization of the banking sector.
\end{abstract}

${ }^{*}$ I am extremely grateful to Viral Acharya, Alexi Savov and Philipp Schnabl for their excellent guidance on this project. I also benefited from comments by Tobias Berg, Paolo Colla (discussant), Vadim Elenev, Robert Engle, Miguel Faria-e-Castro, Xavier Gabaix, Douglas Gale, Aaditya Iyer, Samuel Lee, Andres Liberman, Enrico Perotti, Anthony Saunders, Sascha Steffen, Marti Subrahmanyam, Rangarajan Sundaram, Harald Uhlig, and Ram Yamarthy (discussant) as well as seminar participants at Stern Ph.D. Student Seminar, London Business School TADC, NYU Financial Economics Workshop, First ECB Forum on Central Banking Postersession (Sintra), Bocconi-Carefin Sixth International Banking Conference, University of Amsterdam, and MFM Winter 2015 Meeting for valuable discussions and comments. I also thank the Macro Financial Modeling Group funded by the Alfred P. Sloan Foundation for financial support. A previous version was circulated as "Why Are Banks Not Recapitalized During Crises? A Political Economy Explanation".

${ }^{\dagger}$ NYU Stern School of Business, mcrosign@stern.nyu.edu

${ }_{\ddagger}^{\ddagger}$ Updates: http://people.stern.nyu.edu/mcrosign/ 


\section{Why Are Banks Not Recapitalized During Crises?*}

Motivation and research question The recent European debt crisis unveiled the existence of a vicious loop between sovereign and banks' credit risk. As the former deteriorates, banks are hit through their holdings of domestic government bonds, increasing, in turn, the likelihood of a bailout. The goal of this paper is to study the origins of this deadly embrace and its macroeconomic effects. To this end, I build and test a simple model consistent with three facts observed during the crisis in the Euro periphery: banks (i) increased their holdings of domestic government bonds, (ii) reduced lending to non-financial private sector, and (iii) remained undercapitalized throughout the crisis.

The model In the proposed model, undercapitalized banks tilt their government bond portfolio towards domestic securities as these are highly correlated with other sources of banks' revenues. While, in case of domestic sovereign default, banks are protected by limited liability, home sovereign debt guarantees a high payoff in the good state of the world. In other words, weak banks optimally place a bet on the upside (high return on government bonds) and are protected in the downside (bankruptcy). During sovereign crises, when sovereign yields are high, this "gamblingfor-resurrection" incentive might cause banks to even reduce the supply of private lending to increase holdings of public debt. Anticipating this mechanism, national regulators face a trade-off when setting capital requirements for the domestic financial sector. Compared to sound banks, undercapitalized banks reduce lending to the private sector and, therefore, tax collection. However, during crises, governments may be willing to bear the cost of sub-optimal private lending supply in order to induce banks to act as buyers-of-last-resort for government debt. Moreover, by increasing their debt capacity, governments might attract foreign investors, triggering a "race to the bottom" in capital regulation among different countries. Following recapitalizations of weak domestic banks, sovereigns might experience lower debt capacity and face a higher interest rate on public debt. While having well capitalized banks is generally efficient, national regulators might drive the economy in an inefficient equilibrium with undercapitalized banks.

Supporting empirical evidence I test the model using stress test data provided by the European Banking Authority. I divide banks, according to their pre-crisis leverage, in high- and low-leverage banks and show that more leveraged banks increased the share of domestic securities in the government bond portfolio by $24.1 \%$ during the crisis, compared to only $6.6 \%$ of low leverage banks.

Conclusion Bank capital plays an important role in the formation of potential linkages between sovereign risk and domestic financial sector fragilities. A supranational regulator, that takes into account cross-country spillover effects, is the agent best suited to set capital regulation and to supervise banks. The European banking union is a step in the right direction.

*Short non-technical summary prepared for the $43^{\text {rd }}$ "Long-Term Perspectives for Economic Growth" Economics Conference at the Oesterreichische Nationalbank (15 June 2015). Author: Matteo Crosignani (mcrosign@stern.nyu.edu) 


\section{Introduction}

The recent European debt crisis unveiled the existence of a "diabolic loop" between sovereigns and domestic banks: increased sovereign credit risk impairs the balance sheet of financial institutions that, in turn, rely on government guarantees. ${ }^{1}$ In addition, banks' portfolio choice affects aggregate demand for domestic public debt and, consequently, sovereign borrowing costs. Understanding the origins of this two-way feedback and its general equilibrium effects is crucial to design effective macro-prudential policy and understand fragilities during sovereign crises. In this paper, I document three stylized facts underlying this vicious loop and build a tractable general equilibrium model that rationalizes them, also providing additional empirical implications, that I test using data from the European debt crisis.

The Eurozone periphery drifted into a severe crises in mid-2009, when sovereign yields started diverging from yields in the core countries reaching record high at the end of 2011, when the European Central Bank adopted extraordinary measures to preserve the Euro. ${ }^{2}$ Three facts from the European periphery motivate this paper. First, banks tilted their government bond portfolio towards domestic securities as the home sovereign became riskier. Figure 1 shows the share of total government debt held by domestic banks (dashed blue line) and the 5-Year CDS spread (solid orange line) for Italy, Spain, and Portugal. ${ }^{3}$ The figure documents that the dramatic deterioration of sovereign creditworthiness is matched by the repatriation of public debt on domestic banks' balance sheets. Second, banks' portfolio composition of private and public debt substantially changed as domestic government bonds replaced credit to firms. Figure 2 shows, in levels (tn $€$ ), holdings of domestic government bonds (dashed blue line) and credit to non-financial institutions (solid orange line) for the same three countries. In late 2010 in Spain and Portugal, and in late 2011 in Italy, private credit, started to fall. Third, banks were undercapitalized entering the crisis and regulators failed to both assess the extent of banks' undercapitalization and promptly improve the financial sector soundness. ${ }^{4}$ European policy makers have also been reluctant to implement the portion of Basel III that required banks to comply with stricter capital requirements. ${ }^{5}$

\footnotetext{
${ }^{1}$ See Acharya et al. (forthcoming), Farhi and Tirole (2014), and Brunnermeier (2015).

${ }^{2}$ According to Bloomberg, the 10-Year on-the-run government bonds spreads reached $7.3 \%$ on 25 November 2011 in Italy, $7.2 \%$ on 24 July 2012 in Spain, 7.6\% on 24 July 2012 in Portugal, and $16.6 \%$ on 18 July 2011 in Ireland.

${ }^{3}$ Figure D.1 in Appendix D shows plots from Ireland and Greece. I measure credit risk using CDS as bond spreads (with respect to the German benchmark) incorporate a flight-to-quality price component. Unreported plots using bond spreads are almost identical.

${ }^{4}$ For a discussion of the European regulators neglect in dealing with banks' regulatory capital, see Greenlaw et al. (2012) and Acharya et al. (2014b).

${ }^{5}$ Capital requirements in the Eurozone follow the Capital Requirements Directive (CRD) that imple-
} 


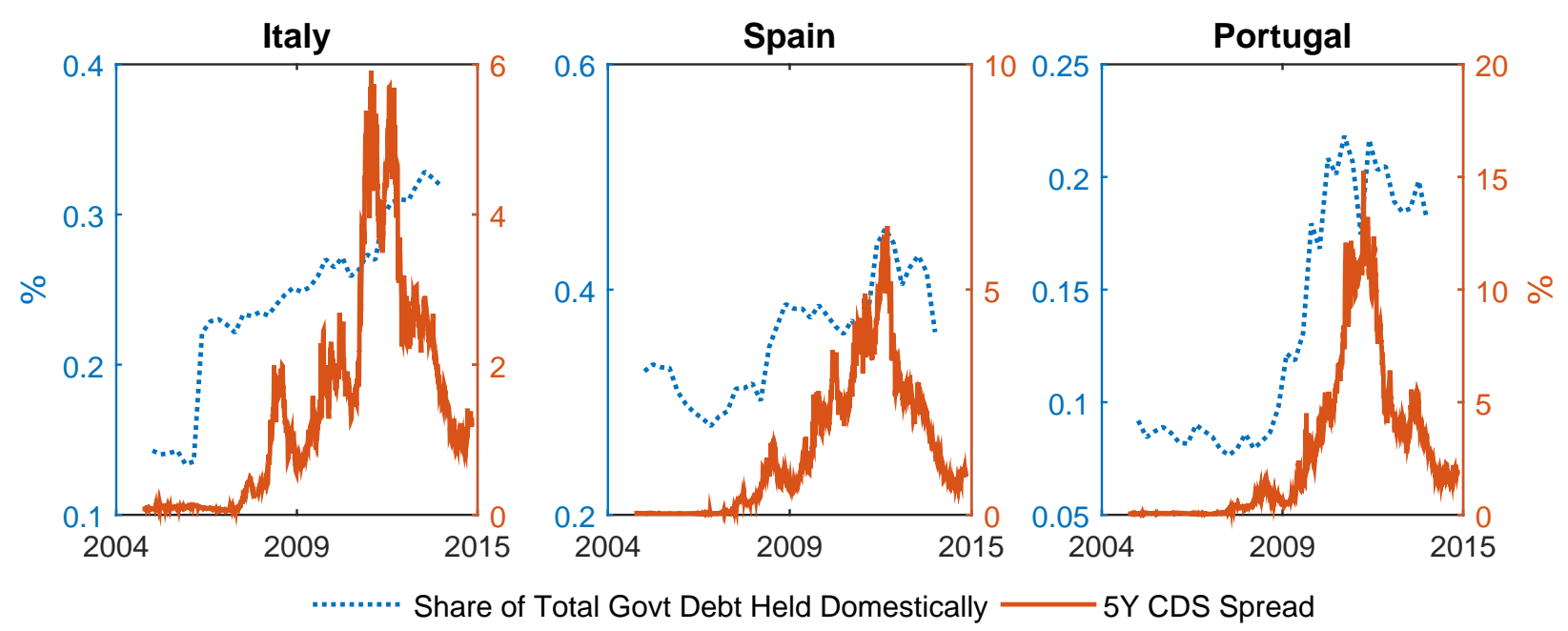

Figure 1: Share of Government Debt Held by Domestic Banks and CDS Spreads. This figure shows the share of sovereign debt owned by domestic banks (solid orange line, primary axis, (\%)) and the 5-Year USD denominated sovereign CDS spread (dotted blue line, secondary axis, (\%)) for Italy, Spain, and Portugal. CDS spreads are from Bloomberg and government debt ownership data is from Arslanalp and Tsuda (2012).

In particular, the fear that higher capital requirements on government bonds would have encouraged a sell off might have played a role as Danièle Nouy admitted in a statement: "Sovereigns are not risk-free assets. That has been demonstrated, so now we have to react. What I would admit is that maybe it's not the best moment in the middle of the crisis to change the rules $[\ldots] " .6$

In this paper, I build a tractable general equilibrium model where banks' portfolio choice is affected by their capitalization. Undercapitalized banks optimally tilt their government bond portfolio towards domestic securities. These are positively correlated with banks' other sources of revenues and are therefore used to gamble for resurrection. Domestic sovereign debt promises the highest payoff in the good state of the world and limited liability protects banks' equity holders in case of domestic sovereign default (Fact 1). As public debt credit risk becomes sufficiently high, risk-shifting banks crowd-out private lending to increase even more their government bond holdings (Fact 2). Anticipating this mechanism, governments face a trade-off when setting capital regulation. On the one hand, well capitalized banks foster growth providing credit to the non-financial private sector. On the other hand, un-

mented the Basel II and Basel III capital standards. Basel III Accord is implemented through CRD IV. The proposal "applies to all EU banks [...] It strengthens their resilience in the long term by increasing the quantity and quality of capital they have to hold." Member states were expected to implement the directive into national law by the end of 2012. The deadline was not respected and the Directive was put in place in January 2014. See European Commission (2011) for details on CRD IV and its implementation.

${ }^{6}$ Danièle Nouy is the Chair of the Supervisory Board of the Single Supervisory Mechanism (SSM). 


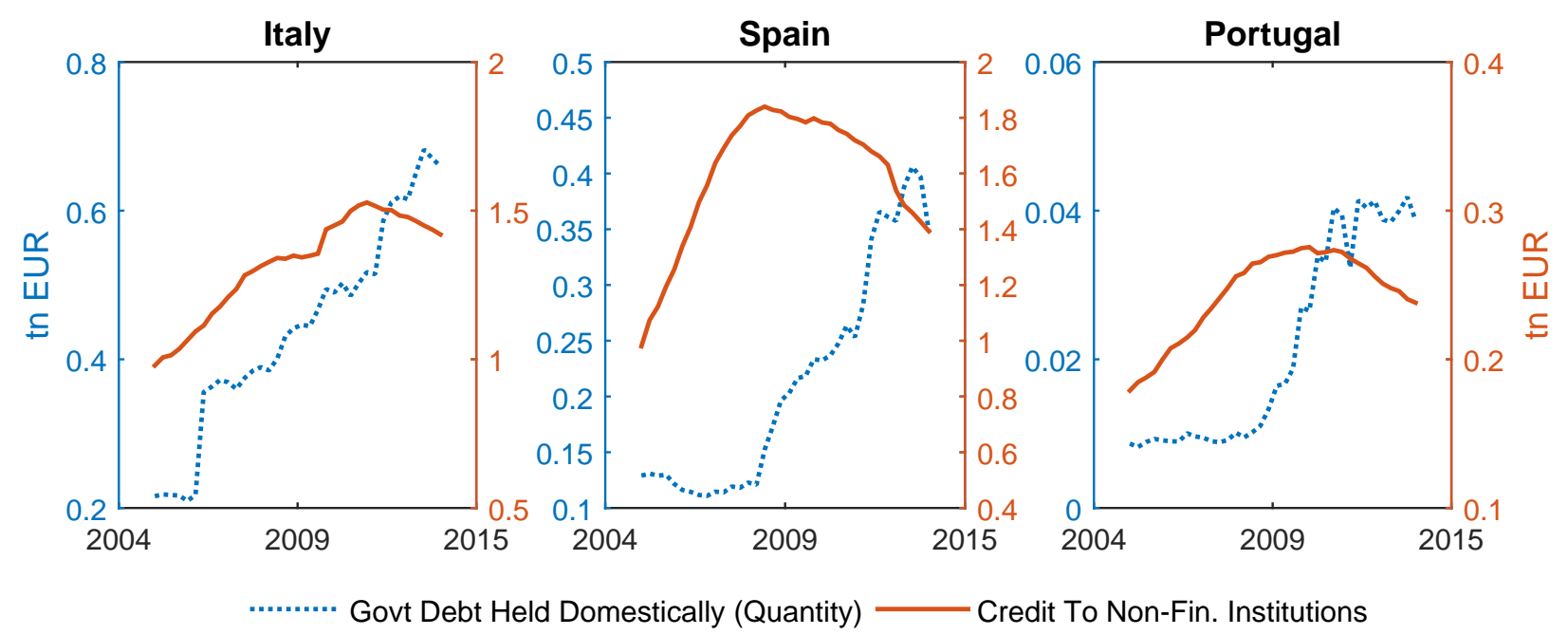

Figure 2: Domestic Government Bond Holdings and Credit To The Non-Financial Private Sector. This figure shows holdings of domestic government bonds by domestic banks (dotted blue line, primary axis, tn $€$ ) and domestic banks' credit to the non-financial private sector (solid orange line, secondary axis, tn $€$ ) for Italy, Spain, and Portugal. Credit to non-financial entities includes credit to non-financial corporations (both private-owned and public-owned), households, and non-profit institutions. Credit is mainly in form of loans and debt securities. Government debt ownership data is from Arslanalp and Tsuda (2012) and data on credit to non-financial entities is from the Bank for International Settlements (BIS).

dercapitalized banks optimally act as buyers of last resort for domestic government debt. Hence, under certain conditions, the government might prefer weak domestic banks (Fact 3).

There are two countries and two dates. Each country has a government and a financial sector. The latter can invest in a domestic private lending technology and in domestic and foreign government bonds. The government maximizes spending by issuing debt and levying taxes on banks' payoff from private lending. This is uncertain. In the good state, the payoff is high and the government has sufficient tax collection to repay bondholders. In the bad state, the payoff is low and the government is forced to default on part of its debt. Banks' portfolio choice crucially depends on whether the limited liability constraint is binding in the bad state of the world. If not binding, banks invest in both domestic and foreign public debt markets. If binding, banks tilt their government bond portfolio towards domestic securities, which perform well in the good state and poorly in the bad state, exactly when all revenues are used to pay the initial private debt. As shocks are uncorrelated across countries this is not the case for foreign government debt as its payoff only depends on the performance of the foreign economy. The high demand for domestic bonds might lower yields, allowing the government to expand supply. Hence, a government with undercapitalized domestic banks may have higher debt capacity and pay lower interest rates at the cost of crowding-out private lending. While recapitalizations are always welfare improving, the government might prefer to have the limited liability constraint binding for domestic banks in the bad state in order to trigger their risk-shifting behavior. 
The model yields two empirical predictions: (i) worse-capitalized banks tilt their government bond portfolio domestically compared to better capitalized banks and, similarly, (ii) geographically undiversified, or "local", banks tilt their government bond portfolio domestically compared to geographically diversified, or "international", banks. I test these hypotheses using bank-level data on sovereign exposures disclosed by the European Banking Authority (EBA) at seven dates between December 2010 and June 2013. The limited sample size of the EBA dataset limits the empirical analysis to the display of consistent correlations and the discussion of possible alternative channels. ${ }^{7}$ First, I analyze the role of capitalization. I exploit the heterogeneity in book leverage in December 2010 to evaluate banks' capitalization and find that the home bias in the government bond portfolio of undercapitalized banks (leverage top quartile) increased by $115 \%$ compared to an increase of $55 \%$ of better capitalized banks (leverage bottom quartile) between March 2010 and June 2013. Second, I analyze the role of geographical diversification. Following a similar strategy, I divide banks according to their geographical diversification using the December 2010 total domestic credit risk exposure. This is not limited to public debt, and includes exposures to residential and commercial real estate, corporations, and institutions. I find that "local" banks increased the home bias in the government bond portfolio by $40 \%$ more compared to "international banks".

Having documented correlations consistent with the gambling-for-resurrection motive, I then discuss alternative explanations, taken from the literature and the public debate. First, many commentators claim that the zero capital requirements on Euro denominated sovereign bonds encouraged Eurozone banks to buy risky peripheral government debt. However, peripheral banks' exposure to peripheral-non-domestic government debt dropped during the crisis confirming that domestic securites, rather than zero risk weight risky securities, became more attractive in this period. For example, Spanish banks reduced their holdings of risky peripheral non-Spanish bonds and increased holdings of domestic bonds, even if both types of securities carried a zero risk weight. Second, moral suasion, or "financial repression", is another common alternative explanation (see Bo and Ivashina (2014)). Under this hypothesis, governments pressure domestic banks to buy their debt during turbulent times. My model can be interpreted as a model of moral suasion as long as the government is more successful in repressing undercapitalized or local banks, which might gamble-for-resurrection incentive even in the absence of the government influence. Admittedly, it might still be that banks increased their holdings of domestic debt in order not to bear the redenomination

\footnotetext{
${ }^{7}$ The EBA is the only publicly available source of information on European peripheral banks' sovereign exposure. It discloses data on only 16 peripheral banks.
} 
risk associated with foreign securities or to increase the chances of a government bailout by making their default more costly for the sovereign. Finally, banks' information advantage regarding domestic securities might have increase during turbulent times.

The remainder of the paper is organized as follows. Section 2 discusses the literature. Section 3 illustrates the baseline model. Section 4 discusses and relaxes the main assumptions. Section 5 shows empirical evidence consistent with the proposed mechanism. Section 6 concludes.

\section{Literature Review}

This paper relates to the literature on the (i) linkages between sovereign and financial sector risks, (ii) the transmission of sovereign shocks through banks, and (iii) regulation and banks' portfolio choice.

First, I contribute to the literature analyzing linkages between sovereign and domestic financial sector. Acharya et al. (forthcoming) models a two-way feedback between the sovereign and the financial sector credit risk. Using CDS data, they find that bailouts funded by government bonds contributed to the increasing sovereign credit risk. Farhi and Tirole (2014) models a "doom loop" that allows for both sovereign debt forgiveness and banking system bailout. The latter encourages banks to diversify as little as possible in order to take advantage of the taxpayers' put. In my model, the sovereign-banks loop originates from the government inducing banks to gamble for resurrection using its public debt (Jensen and Meckling (1976)). Brutti and Saure (2013) empirically documents the importance of cross-border linkages of financial institutions. My model allows for international spillovers, therefore giving theoretical foundations to the documented stylized facts. Acharya and Steffen (forthcoming) shows that large and undercapitalized European banks have increased holdings of peripheral bonds during the crisis. The contribution of my paper is to propose a theory supporting their empirical facts. Buch et al. (2013) also analyzes banks' government bond portfolio choice showing that worse-capitalized banks hold more domestic bonds. These findings about a core European country complement my analysis of the periphery. Drechsler et al. (2014) analyzes collateral pledged at the ECB between 2007 and 2010. They find that weakly-capitalized banks pledged riskier collateral at the ECB and borrowed more. In the model presented in the remainder of the paper, I abstract away from bank funding to focus on banks portfolio choice. Drechsler et al. (2014) shows empirically that this is a mild assumption as the lender of last resort did not discriminate between illiquid and risk-shifting banks. Bo and Ivashina (2014) shows that, across large banks, there is little correlation between bank health and its home bias in government bond holdings. Using a methodology developed in Bo and Ivashina (forthcoming), the authors 
find evidence of moral suasion in the Euro debt crisis. ${ }^{8}$ Hildebrand et al. (2012) finds that German banks, between 2006 and 2011, change their portfolio choice favoring securities that are eligible as collateral for central bank operations. Gennaioli et al. (2012) analyzes holdings of government bonds from 191 countries. They find that banks increase their exposures to public bonds during sovereign defaults, especially when expected returns on government bonds are high. Their findings constitute an empirical foundations for my contribution. Broner et al. (2010) shows that sovereign risk is eliminated by the presence of functioning secondary markets that, during crises, reallocate the government debt domestically. Finally, Gennaioli et al. (2014) shows that government defaults are costly because they destroy the balance sheets of domestic banks.

Second, my findings adds to the literature on the transmission of financial crises to firms and households through the reduced supply of credit. In the context of the Lehman collapse, Ivashina and Scharfstein (2010) and Santos (forthcoming) show that banks that were more affected by the shock reduced volume of credit and charged higher rates compared to less affected banks. Chodorow-Reich (2014) shows that the bank lending channel contributed to a reduction in employment in small and medium firms. A recent strand of the literature has focused on the transmission during sovereign crises. Bocola (2013) and Perez (2014) build general equilibrium models to illustrate the transmission of these shocks. The first shows that news about a potential sovereign default has a negative impact on lending as borrowers become riskier and funding becomes harder to get for banks. The second illustrates how a sovereign crisis might also cause banks to replace government bonds with less profitable projects to transfer resources through time, negatively affecting lending. Several papers have also tried to document the transmission empirically. Acharya et al. (2014a) finds, using the European syndicated loan market, that borrowers relying on banks affected by the Euro sovereign crisis suffered from diminished credit supply, negatively affecting capital expenditures, sales growth and employment growth. Popov and Van Horen (2013) and De Marco (2014) also use the syndicated loan market and find that sovereign bond holdings had a negative impact on the supply of credit. Almeida et al. (2014) provides an additional channel through which increased sovereign risk is transmitted to the real sector. They find that sovereign credit ratings downgrade cause, almost always, the downgrade of a firm whose rating is equal or above the sovereign one (prior to the downgrade). Finally, Bofondi et al. (2013) finds, using Italian credit registry data, that Italian banks decreased credit and increased interest rates more than Italian subsidiaries of foreign banks. Their results, again,

\footnotetext{
${ }^{8}$ Moral suasion is also analyzed in Reinhart and Sbrancia (forthcoming), Chari et al. (2015), and De Marco and Macchiavelli (2014).
} 
point towards a negative feedback effect originating from the sovereign.

Third, this paper relates to the literature on regulation and banks' portfolio choice. Diamond and Rajan (2011) show that highly leveraged institutions might gamble for resurrection by holding on to illiquid assets, effectively behaving as a "illiquidity seekers". The sub-optimal credit supply of weakly capitalized banks is studied in Caballero et al. (2008) that shows how Japanese banks, in the early 1990s, kept extending loans to insolvent "zombie" borrowers hoping in their recovery or in a government bailout. Recapitalizations receive attention in both the empirical and theoretical literature. Philippon and Schnabl (2013) model an efficient recapitalization scheme that reduces the debt overhang problem. Empirically, Homar (2014) and Giannetti and Simonov (2013) show that, following large recapitalizations, banks increase lending in the European and Japanese crises context, respectively. Uhlig (2013) analyzes a setting, similar to the one here proposed, where home bias and cheap borrowing by risky countries arise as bonds can be used for repurchase agreements

with a common central bank. In my model banks also voluntarily choose to buy government bonds, but such preference originates from risk-shifting. Finally, Boz et al. (2014) illustrates how sovereign defaults amplify the business cycle and suggests that more stringent capital requirements improve welfare. The benefits of more stringent capital requirements are also analyzed quantitatively, in a quantitative framework, in Begenau (2015).

\section{Model}

In this section I setup and solve the baseline model. I make some assumptions that I discuss and relax in Section 4. The economy starts at $t=0$ and terminates at $t=1$. There are two symmetric countries $i \in \mathcal{I}$, where $\mathcal{I}=\{A, B\}$. Each country has a government and a banking sector. There is universal risk neutrality and no discounting. In the following subsection, I describe the model setup for one country omitting, for simplicity, the country superscripts.

\subsection{Setup}

There is a representative bank with balance sheet of size one, debt $L \in[0,1]$ maturing $t=1$, and equity $1-L$. It maximizes profits investing in domestic government bonds, foreign government bonds, and a domestic lending technology.

Assumption 1: Banks cannot invest in the foreign lending technology.

The lending technology is risky as it can be hit by a negative shock between $t=0$ and $t=1$ : an investment of $k$ at $t=0$ yields $\epsilon_{H} f(k)$ with probability $\theta$ and $\epsilon_{L} f(k)$ with probability $1-\theta$ at $t=1$, where $\theta \in(0,1)$ and $\epsilon_{H}>\epsilon_{L}$.

Assumption 2: Lending technology shocks are uncorrelated across countries. 

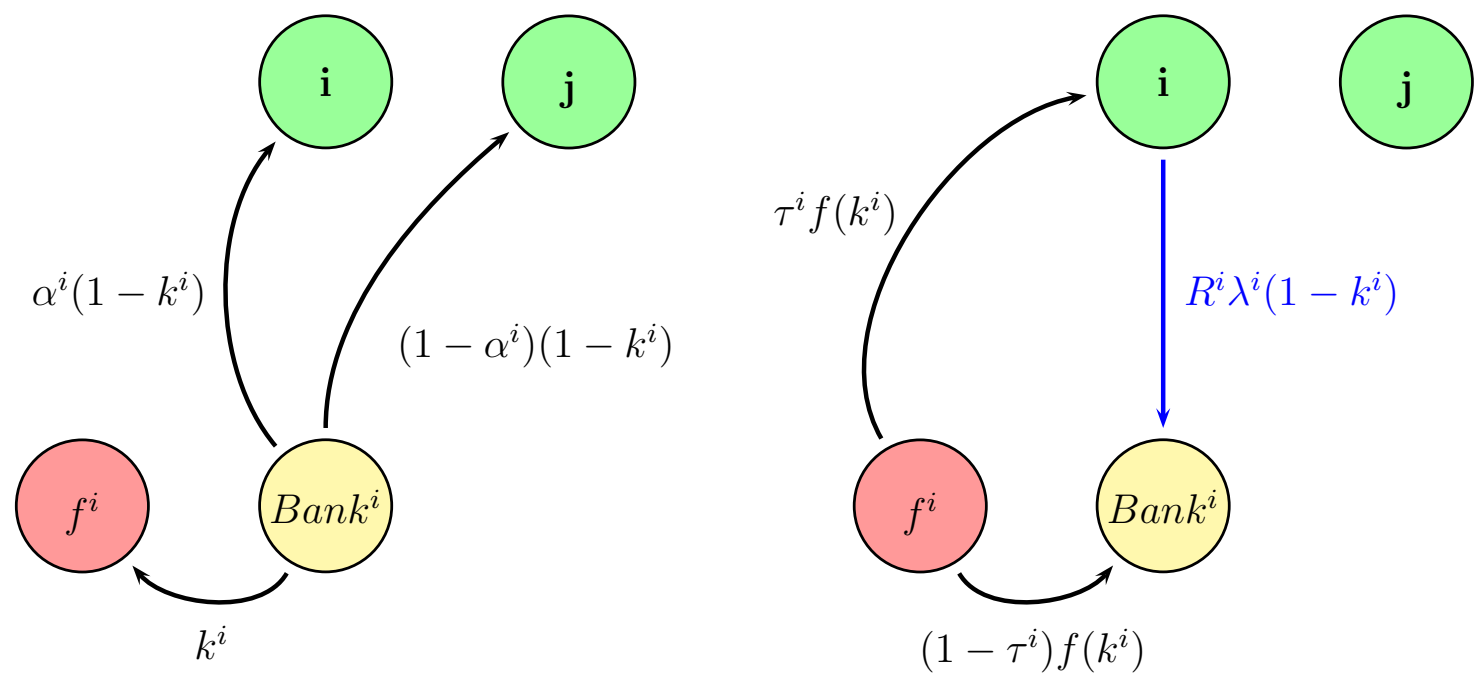

Figure 3: Investment Opportunities. The left panel of this figure illustrates the investment opportunities and of the financial sector in country $i \in \mathcal{I}$, which can invest in (i) the (domestic) lending technology $f^{i}$, (ii) domestic government bonds, and (iii) foreign government bonds. The choice variable $\alpha$ captures the home bias of the financial sector. The right panel shows the payoff from (i) and (ii), following the realization of the lending technology revenues.

I assume that $f(\cdot)$ is continuous, strictly increasing, strictly concave, and satisfies Inada conditions. Banks can also invest in the two government bond markets. In particular, they invest $\alpha(1-k)$ in the domestic market and $(1-\alpha)(1-k)$ in the foreign market. Domestic government bonds pay an (endogenous) gross interest rate $R$. Similarly, foreign government bonds pay an (endogenous) gross interest rate $R^{*}$. The choice variable $\alpha \in[0,1]$ captures the home bias, in the government bond portfolio, of the financial sector. If $\alpha=1$ there is "perfect" home bias and banks invest only domestically. On the other hand, if $\alpha=0$, banks invest in foreign bonds only. Banks maximize profits and are subject to limited liability. The left panel of Figure 3 illustrates the investment opportunities for banks in $i \in \mathcal{I}$ in this economy. The government starts with zero initial debt and wants to maximize spending by issuing one-period maturity debt $D$ and taxing revenues from private lending at $t=1$ at an exogenous tax rate $\tau$. Note that tax collection is uncertain as the tax base, given by banks' revenues from the lending technology, depends on the state $s \in \mathcal{S}$, where $\mathcal{S}=\{H, L\}$. The government cannot save and must fund a non-discretionary level of public expenditure $g$ every period. Hence, should tax collection minus expenditures be lower than the payments due to bondholders, the government defaults on part of its debt, applying an haircut $1-\lambda$. Conditional on having funds, the government always repays its debt. ${ }^{9}$ In Section 3.6, I first

\footnotetext{
${ }^{9}$ The model can accommodate strategic default, introducing an exogenous cost of default at $t=1$.
} 
solve the model assuming that the government spending is worthless and then assuming that spending is non-wasteful. Figure 4 illustrates the timeline of the economy for a representative country.

Debt Capacity Investors anticipate that the government might default and are therefore willing to invest in public debt if and only if payments due to bondholders at $t=1$ are less or equal the expected tax collection minus the non-discretionary spending $g$

$$
D R \leq \mathbb{E}(\epsilon) \tau f(k)-g
$$

I rewrite $g$, for simplicity, as a fraction $\gamma$ of tax collection in the bad state of the world. Formally,

$$
g=\gamma \tau \epsilon_{L} f(k)
$$

Rearranging the two expressions above, we obtain the government debt capacity

$$
D \leq \frac{\tau \Delta_{\epsilon} f(k)}{R}
$$

where $\Delta_{\epsilon}=\theta \epsilon_{H}+(1-\theta-\gamma) \epsilon_{L}$ is the share of tax collection that is used to repay bondholders. ${ }^{10}$ The government is constrained when issuing debt as investors are not willing to buy public bonds if (1) is violated.

\subsection{Agents' Problem and Equilibrium Definition}

Having derived the government debt capacity, I now define the equilibrium and illustrate the optimization problem of government and banks in a representative country. At $t=0$, banks maximize profits investing in domestic government bonds, non-domestic government bonds, and private lending, subject to limited liability.

$$
\begin{aligned}
& \max _{\alpha, k}[\mathbb{E}(\Pi)-L]^{+} \\
& \text {s.t. } \\
& \mathbb{E}(\Pi)=\underbrace{(1-\tau) \mathbb{E}(\epsilon) f(k)}_{\begin{array}{c}
\text { revenues } \\
\text { from private lending }
\end{array}}+\underbrace{\alpha(1-k) \mathbb{E}(\lambda) R}_{\begin{array}{c}
\text { revenues } \\
\text { from domestic bonds }
\end{array}}+\underbrace{(1-\alpha)(1-k) \mathbb{E}^{*}\left(\lambda^{*}\right) R^{*}}_{\begin{array}{c}
\text { revenues } \\
\text { from foreign bonds }
\end{array}}
\end{aligned}
$$

\footnotetext{
${ }^{10} \mathrm{As} \gamma$ is a constant, note that $g$ depends on the equilibrium investment $k$ in the lending technology.
} 
Govt issues $D$

Shock hits

Banks have balance sheet of size 1 and debt $L$
Govt announces tax rate $\tau$ and spends $g$

Banks make investm decision $\alpha$ and $k$

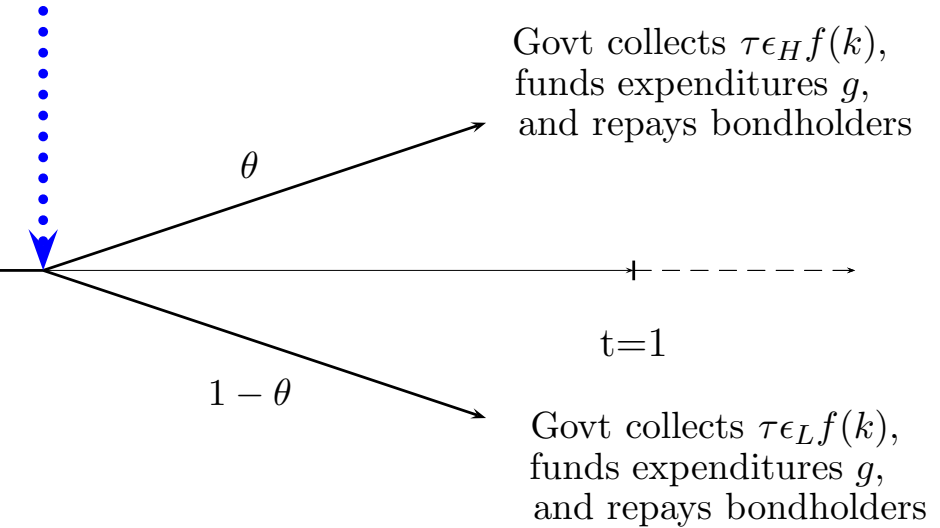

Figure 4: Timeline. This figure illustrates the timeline of the economy for a representative country.

where the ${ }^{*}$ superscript indicates foreign quantities and prices, or expectations taken with respect to the foreign probability $\theta^{*}$. Note that the uncertainty about the productivity parameter $\epsilon$ spreads to the sovereign bond markets as governments repay bondholders with uncertain tax collection at $t=1$. The possibility of partial default (in case tax collection is lower than payments due to bondholders) is captured by the recovery value $\lambda \in[0,1]$. When $\lambda<1$ the government defaults being able to repay only a fraction $\lambda$ of the payments due. In the extreme case when $\lambda=0$ the government defaults on the entire debt.

In equilibrium, governments maximize spending, banks maximize profits, and the two bond markets clear. Hereafter, I will use the following equilibrium definition.

Definition 1. Given initial debt levels $L^{i}$, tax rates $\tau^{i}$, lending technologies $f^{i}$, probabilities $\theta^{i}$, spending $g^{i}$, where $i \in \mathcal{I}$, an equilibrium is

- prices of government bonds $R^{i}$

- public debt issuance $D^{i}$

- recovery values on public debt $\lambda_{s}^{i}$, for $s \in \mathcal{S}$

- financial sectors' investment decisions $\alpha^{i}, k^{i}$

such that

- bond markets clear

- financial sectors maximize profits

- governments maximize spending

According to market clearing conditions, for each country, the sum of domestic and foreign demand for public bonds must be equal to the government supply. The two bond market 
clearing conditions are

$$
\begin{aligned}
& \alpha^{A}\left(1-k^{A}\right)+\left(1-\alpha^{B}\right)\left(1-k^{B}\right)=D^{A} \\
& \alpha^{B}\left(1-k^{B}\right)+\left(1-\alpha^{A}\right)\left(1-k^{A}\right)=D^{B}
\end{aligned}
$$

In each of the two equations above the first (second) term on the left hand side is the domestic (foreign) demand for sovereign bonds. The government wants to maximize spending and therefore chooses the highest debt issuance $D$ subject to (1).

$$
D=\frac{\tau \Delta_{\epsilon} f(k)}{R}
$$

While in the good state tax collection minus expenditures is high enough to repay bondholders, the government is forced, in the bad state, to write-down part of its debt, applying an haircut $1-\lambda<1$. The following lemma formalizes the intuition.

Lemma 1. The government only defaults in the bad state $\left(\lambda_{H}^{i}=1, \forall i\right)$. The government debt recovery value in the bad state is $\lambda_{L}^{i}=\epsilon_{L}^{i}\left(1-\gamma^{i}\right)\left(\Delta_{\epsilon}^{i}\right)^{-1}, \forall i$.

Having obtained the government bond supply, I now turn to solve banks' problem. Given Inada conditions, banks always invest $k>0$ in lending. Depending on whether the limited liability constraint binds in the bad state, there are two relevant cases: (i) if not binding (the initial private debt $L$ is low enough), banks are "well capitalized" (W case) and solve (2); (ii) if binding (initial private debt $L$ is high enough), banks are "undercapitalized" (U case) and solve

$$
\begin{aligned}
& \max _{\alpha, k} \theta\left[\Pi_{H}-L\right] \\
& \text { s.t. } \\
\Pi_{H}= & (1-\tau) \epsilon_{H} f(k)+\alpha(1-k) R+(1-\alpha)(1-k) \mathbb{E}^{*}(\lambda) R^{*}
\end{aligned}
$$

where the subscript $H$ indicates the good state of the world. The above maximization problem captures the risk-shifting motive of undercapitalized banks: as in the bad state profits are entirely used to repay bondholders, banks only care about the good state and have an incentive to gamble for resurrection (Jensen and Meckling (1976)). I formally characterize the relation between the initial debt $L$ and banks' capitalization in Section 3.5. Figure 5 illustrates, for each case, the payoffs at $t=1$. To get some intuition on the mechanism, I solve for the optimal home bias $\alpha$ in the two cases and get 


\section{W case}

Limited liability never binds.

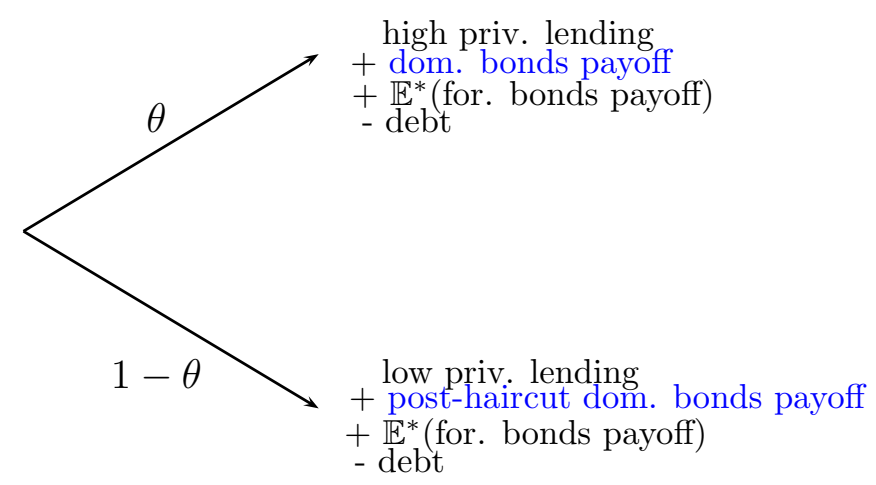

\section{U case}

Limited liability binds in the bad state $s=L$.

Figure 5: Financial Sector Problem. This figure shows the payoffs of the financial sector in the good state of the world (w.p. $\theta$ ) and in the bad state of the world (w.p. $1-\theta$ ). The left panel shows the case where the limited liability constraint never binds (W case) and the right panel shows the case where the limited liability constraint binds in the bad state (U case).

$$
\begin{aligned}
& \text { In the U case } \begin{cases}\alpha=1 & \text { if } R>\mathbb{E}^{*}\left(\lambda^{*}\right) R^{*} \\
\alpha=0 & \text { if } R<\mathbb{E}^{*}\left(\lambda^{*}\right) R^{*} \\
\alpha \in[0,1] & \text { if } R=\mathbb{E}^{*}\left(\lambda^{*}\right) R^{*}\end{cases} \\
& \text { In the W case } \begin{cases}\alpha=1 & \text { if } \mathbb{E}(\lambda) R>\mathbb{E}^{*}\left(\lambda^{*}\right) R^{*} \\
\alpha=0 & \text { if } \mathbb{E}(\lambda) R<\mathbb{E}^{*}\left(\lambda^{*}\right) R^{*} \\
\alpha \in[0,1] & \text { if } \mathbb{E}(\lambda) R=\mathbb{E}^{*}\left(\lambda^{*}\right) R^{*}\end{cases}
\end{aligned}
$$

where $\mathbb{E}(\lambda)=\theta+\lambda(1-\theta) \in(0,1)$ and $\mathbb{E}^{*}\left(\lambda^{*}\right)=\theta^{*}+\lambda^{*}\left(1-\theta^{*}\right) \in(0,1)$. Given risk neutrality, a well capitalized financial sector ( $W$ case) invests only in the government debt with the highest risk-adjusted return $\mathbb{E}\left(\lambda^{i}\right) R^{i}$. On the other hand, domestic government bonds become relatively more attractive for undercapitalized banks ( $U$ case). In fact, investing in foreign bonds is less profitable for them as revenues are entirely used to repay the initial private debt $L$ in the bad state.

The Euro periphery during the recent debt crisis is the ideal laboratory for the proposed model. ${ }^{11}$ For example, according to this mechanism, a highly levered Italian bank with

\footnotetext{
${ }^{11}$ The European periphery exhibited the following characteristics during the crisis: (i) risky sovereign debt, (ii) firms heavily dependent on bank loans, (iii) little diversification of banks' (public and private) lending, (iv) unique currency, and (v) poorly capitalized banks.
} 
substantial lending to the domestic economy, might have an incentive to buy domestic bonds, rather than German or Spanish bonds. In case of Italian sovereign default, the bank would go bankrupt in any case (even if it had purchased foreign bonds) since its revenues are highly correlated with the performance of the home sovereign. By investing in Italian securities, the bank can exploit the positive correlation in the good state (high revenues from lending and bonds), while being protected by limited liability in case of sovereign default.

In the remainder of this section, I solve a baseline version of the model assuming that the two countries are identical, except for the initial level of debt private debt $L^{i}$ so that results are solely driven by different levels of bank capitalization. In particular, in the next two subsection, I show that (i) when both financial sectors are well capitalized there is perfect risk sharing, (ii) undercapitalization induces home bias in equilibrium, and (iii) governments with undercapitalized domestic banks might pay lower interests on debt at the cost of crowding out private lending.

\subsection{Well Capitalized Banks}

As anticipated, I assume that, for the moment, the two countries are identical and differ only in the level of private debt $L^{i}$.

Assumption 3: The two countries have identical $\theta \in(0,1), \tau \in(0,1), f(\cdot)$, and $\lambda$.

Depending on the financial sectors' capitalization, the economy can be in four states, $W W$, $U W, W U, U U$, where the first (second) letter refers to whether the financial sector of country $A$ (country $B$ ) has high or low initial bank debt. For example, the $U W$ state corresponds to the case where country $A$ financial sector is undercapitalized and country $B$ financial sector is well capitalized. First, I analyze the case where both financial sectors are well capitalized. In this benchmark scenario, in equilibrium, there is perfect risk sharing as banks invest in both sovereign bonds and have the same home bias.

Proposition 1. Financial sectors, when both well capitalized, have the same home bias in equilibrium.

By symmetry, both banks choose the same investment $k^{i}=k$ in the lending technology and then allocate the same share $\alpha^{i}=\alpha$ of the remaining unit endowment to the domestic government debt. There is a continuum of equilibria characterized by different levels of banks' home bias. The left panel of Figure 6 shows a high home bias equilibrium where both financial sectors allocate the largest relative share of their government bond portfolio domestically. This is the equilibrium observed in the data where, for the majority of the countries, domestic investors own the largest share of the public debt. The right panel shows the case where both governments face a sizable foreign demand for their bonds. Crucially, quantities and prices do not depend on the home bias which is indeterminate in equilibrium. 

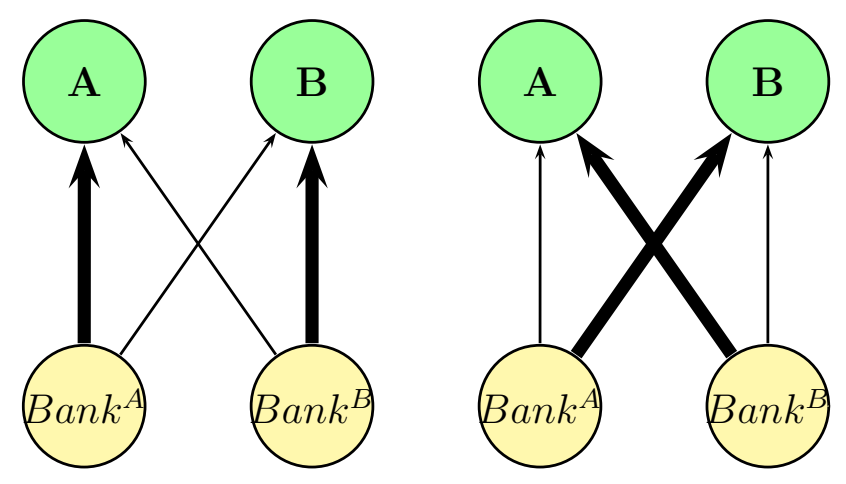

Figure 6: $\boldsymbol{W} \boldsymbol{W}$ Equilibria. This figure illustrates two specific equilibria taken from the continuum of equilibria in the $W W$ region. The left panel illustrates a high home bias equilibrium. The right panel illustrates a low home bias equilibrium.

I obtain closed-form solutions using a simple square root function for the lending technology $(f(k)=\sqrt{k})$. With this simplification, the model yields intuitive expressions for lending, government yields, and public debt.

$$
\begin{aligned}
k_{W W}^{i} & =\frac{(1-\tau) \mathbb{E}(\epsilon)}{(1-\tau) \mathbb{E}(\epsilon)+2 \tau \mathbb{E}(\lambda) \Delta_{\epsilon}} \\
R_{W W}^{i} & =\frac{1}{2 \mathbb{E}(\lambda)}\left(\mathbb{E}(\epsilon)(1-\tau)\left(\mathbb{E}(\epsilon)(1-\tau)+2 \mathbb{E}(\lambda) \tau \Delta_{\epsilon}\right)\right)^{1 / 2} \\
D_{W W}^{i} & =\frac{2 \tau \mathbb{E}(\lambda) \Delta_{\epsilon}}{\mathbb{E}(\epsilon)(1-\tau)+2 \tau \mathbb{E}(\lambda) \Delta_{\epsilon}}
\end{aligned}
$$

for all $i \in \mathcal{I}$, where the $W W$ subscripts refer to the case where both financial sectors are well capitalized. Private lending is decreasing in the tax rate: as the tax base is exclusively made by revenues from the lending technology, a higher $\tau$ reduces the after-tax revenues from private lending. However, in a world with higher taxes, banks tilt their portfolio toward government bonds. This is the intuition in Acharya and Rajan (2013) where the government might use a "financial repression tax" to divert private sector investment from lending to domestic public debt. In the two-country economy presented here the government cannot control which bond market banks are going to invest in. In particular, it might well be that they allocate all their sovereign debt portfolio non-domestically, making the financial repression tax potentially useless. On the other hand, private lending is increasing in government credit risk $\gamma$. With higher non-discretionary expenditures, the government is forced to write-down a larger share of its debt in the bad state: ceteris paribus, government debt becomes riskier and banks invest more in private lending. Higher $\gamma$ also lowers the government 
bond supply as investors realize that the government default might be particularly harsh. In equilibrium, yields are negatively affected by an increase in $\gamma$ as the supply effect is stronger than the demand effect.

\subsection{Banks' Portfolio Choice}

Having analyzed the world with two well capitalized financial sectors $(W W)$, I now ask what is the equilibrium when the limited liability constraint binds in the bad state for one or more financial sectors. As discussed, an undercapitalized bank develops a preference, within the government debt portfolio, for domestic securities. These perform well in the good state and poorly in the bad state, exactly when all revenues are used to pay the private debt $L$. As shocks are uncorrelated across countries, this is not the case for foreign government bonds as their payoff only depends on the performance of the foreign economy. ${ }^{12}$ In equilibrium, an undercapitalized banking sector invests only domestically $(\alpha=1)$, regardless of the capitalization of the foreign banking sector.

Proposition 2. (Home Bias) An undercapitalized financial sector has perfect home bias in equilibrium.

Governments with undercapitalized domestic financial sectors are in "financial autarky", as their entire stock of public debt outstanding is held by domestic banks. To understand the origin of this perfect home bias, I separately analyze the case where both banks are undercapitalized $(U U)$ and the case where one financial sector is undercapitalized and one is well capitalized $(U W$ and $W U)$.

Assumption 4. The lending technology has a square-root functional form $f(k)=\sqrt{k}$.

Similar to the benchmark case discussed in the previous subsection, I assume, without loss of generality, a square root production function to get closed-form solutions. I also keep this assumption going forward as exact expressions for quantities and prices provide intuition on the channels at work. First, suppose that the economy is in the $U U$ case, where both financial sectors are undercapitalized. Closed-form solutions are

\footnotetext{
${ }^{12}$ Section 4.2 analyzes an economy where country shocks are correlated.
} 


$$
\begin{aligned}
k_{U U}^{i} & =\frac{(1-\tau) \epsilon_{H}}{(1-\tau) \epsilon_{H}+2 \tau \Delta_{\epsilon}} \\
R_{U U}^{i} & =\frac{1}{2}\left((1-\tau) \epsilon_{H}\left((1-\tau) \epsilon_{H}+2 \tau \Delta_{\epsilon}\right)\right)^{1 / 2} \\
D_{U U}^{i} & =\frac{2 \tau \Delta_{\epsilon}}{(1-\tau) \epsilon_{H}+2 \tau \Delta_{\epsilon}}
\end{aligned}
$$

for all $i \in \mathcal{I}$, where the $U U$ subscripts indicate an economy where both countries have undercapitalized banks. Similar to the $W W$ equilibrium, private lending is decreasing in the tax rate and increasing in sovereign risk $\gamma$. Government yields are also decreasing in $\gamma$. Higher uncertainty (lower $\theta$ ) reduces the supply of government debt as investors fear that the government is more likely to default in the bad state. Interestingly, there is no effect of $\theta$ on demand as banks now care only about the good state, regardless of its likelihood. Hence, in equilibrium, sovereign yields decrease as $\theta$ increases.

I now turn to compare quantities and prices between the $U U$ and $W W$ equilibria. While Proposition 1 showed that banks tilt, in the $U U$ case, their government bond portfolio towards domestic securities, the effect of poor capitalization on the choice between private lending and government bonds is ambiguous, as both assets yield a high payoff in the good state and a low payoff in the bad state. Intuitively, undercapitalized banks have an incentive to gamble for resurrection and can do so using either private lending or government bonds. The choice between the two depends on the respective payoffs: the security best suited to risk-shift yields the highest payoff in the good state and lowest payoff in the bad state.

Corollary 1. (Crowding-Out) If $\gamma>1-\theta$, in an economy with undercapitalized domestic banks (UU), governments have higher debt capacity, pay lower rates and banks reduce lending, compared to an economy with well capitalized banks ( $W W$ ).

The condition $\gamma>1-\theta$ can be rewritten in terms of recovery value as $\lambda<\frac{\epsilon_{L}}{\epsilon_{H}}$, i.e. the bond recovery value has to be low enough to ensure that banks choose public debt to risk-shift. By tilting their portfolio towards government bonds, banks crowd-out private lending. On the other hand, if the domestic sovereign debt recovery value in the bad state is high enough, undercapitalized banks reduce their investment in sovereign market to invest more in private lending. In particular, we can rearrange the condition in Corollary 1 to write

$$
\gamma>1-\theta \Longleftrightarrow \lambda<\frac{\epsilon_{L}}{\epsilon_{H}} \Longleftrightarrow\left(\frac{\mathbb{E}\left(\text { DomGovtBond }_{W W}\right)}{\mathbb{E}\left(\text { PrivLendinG }_{W W}\right)}\right)<\left(\frac{\mathbb{E}\left(\text { DomGovtBond }_{U U}\right)}{\mathbb{E}\left(\text { PrivLendinG }_{U U}\right)}\right)
$$


The left hand side of the last inequality is the ratio of expected payoff from domestic government bonds and private lending in the case a bank is well capitalized. The right hand side is the same ratio in the case a bank is undercapitalized. The effect of banks' portfolio choice on prices and government debt capacity then arises in equilibrium. Undercapitalized banks buy more domestic bonds reducing lending $\left(k_{U U}<k_{W W}\right)$, compared to well capitalized banks. The resulting lower tax collection reduces the government debt capacity as investors fear that the sovereign might be unable to repay them at $t=1$. However, in equilibrium, the high demand for bonds lowers government yields, offsetting the negative effect of lower tax collection. Hence, a government with high levered domestic banks has higher debt capacity $\left(D_{U U}>D_{W W}\right)$ and pays a lower interest rate $\left(R_{U U}<R_{W W}\right)$. Given that the general equilibrium effect operates through prices, we can isolate a risk-shifting term $\eta$ in the $R_{U U}$ price as follows

$$
\begin{aligned}
R_{W W} & =\frac{1}{2}\left(\frac{\mathbb{E}(\epsilon)}{\mathbb{E}(\lambda)}(1-\tau)\left(\frac{\mathbb{E}(\epsilon)}{\mathbb{E}(\lambda)}(1-\tau)+2 \tau \Delta_{\epsilon}\right)\right)^{1 / 2} \\
R_{U U} & =\frac{1}{2}\left(\frac{\mathbb{E}(\epsilon)}{\mathbb{E}(\lambda)} \eta(1-\tau)\left(\frac{\mathbb{E}(\epsilon)}{\mathbb{E}(\lambda)} \eta(1-\tau)+2 \tau \Delta_{\epsilon}\right)\right)^{1 / 2}
\end{aligned}
$$

where

$$
\eta=\frac{\epsilon_{H} \mathbb{E}(\lambda)}{\mathbb{E}(\epsilon)}
$$

The term $\eta>0$ represents the general equilibrium effect of the banks' gamble for resurrection. When $\eta \neq 1$, the portfolio choice of undercapitalized banks distorts government debt prices. In particular, if $\eta<1$, the government pays a lower interest rate on its debt thanks to the higher domestic demand for its bonds.

Assumption 5: $\gamma>1-\theta$.

I assume now that the parameters correspond to the aforementioned crowding-out case and solve the $U W$ case, when country $A$ has undercapitalized domestic banks and country $B$ as well capitalized domestic banks. ${ }^{13}$ Note that the $W U$ case trivially follows by symmetry. In equilibrium, both countries are, again, in financial autarky, but country $A$ faces a higher demand for its government bonds compared to country $B$. In the latter, banks invest less in public debt and more in the private lending technology. Equilibrium quantities and prices

\footnotetext{
${ }^{13} \eta<1$ if and only if $\lambda>1-\theta$.
} 
are given by

$$
\begin{aligned}
R_{U W}^{A} & =R_{U U} \\
R_{U W}^{B} & =R_{W W} \\
k_{U W}^{A} & =k_{U U} \\
k_{U W}^{B} & =k_{W W} \\
D_{U W}^{A} & =D_{U U} \\
D_{U W}^{B} & =D_{W W}
\end{aligned}
$$

There are two interesting results arising from this equilibrium. First, the undercapitalization of one financial sector causes "perfect" home bias in the entire economy. The transmission operates through prices: banks in country $A$ gamble for resurrection investing in domestic bonds lowering the corresponding government bond yield in equilibrium. Hence, well capitalized banks in country $B$ also tilt their government bond portfolio domestically, as the foreign yield is too low. Second, similar to the $U U$ and $W W$ cases, quantities and prices only depend on domestic banks' capitalization and the economy is in financial autarky.

Note that banks' capitalization has up till now been vaguely defined based on whether the limited liability constraint is binding in the bad state. The next subsection formalizes this notion deriving endogenous debt thresholds.

\subsection{Banks' Capitalization}

What determines whether a bank is undercapitalized or well capitalized? I here show that there exist an endogenous debt threshold $\bar{L}$ such that, in equilibrium, a bank is well capitalized if $L \leq \bar{L}$ and undercapitalized if $L>\bar{L}$. To get some intuition, recall that a bank is undercapitalized when the limited liability constraint binds in the bad state. In such case, with perfect home bias, the financial sector generates revenues only from the lending technology and the non-defaulted portion of domestic sovereign debt. Hence, in equilibrium, the payoff in the bad state of the world is

$$
\begin{aligned}
& {\left[(1-\tau) \epsilon_{L} f(k)+\lambda_{L}(1-k)(1+r)-L\right]^{+} } \\
= & {[(1-\tau \gamma) f(k)-L]^{+} }
\end{aligned}
$$



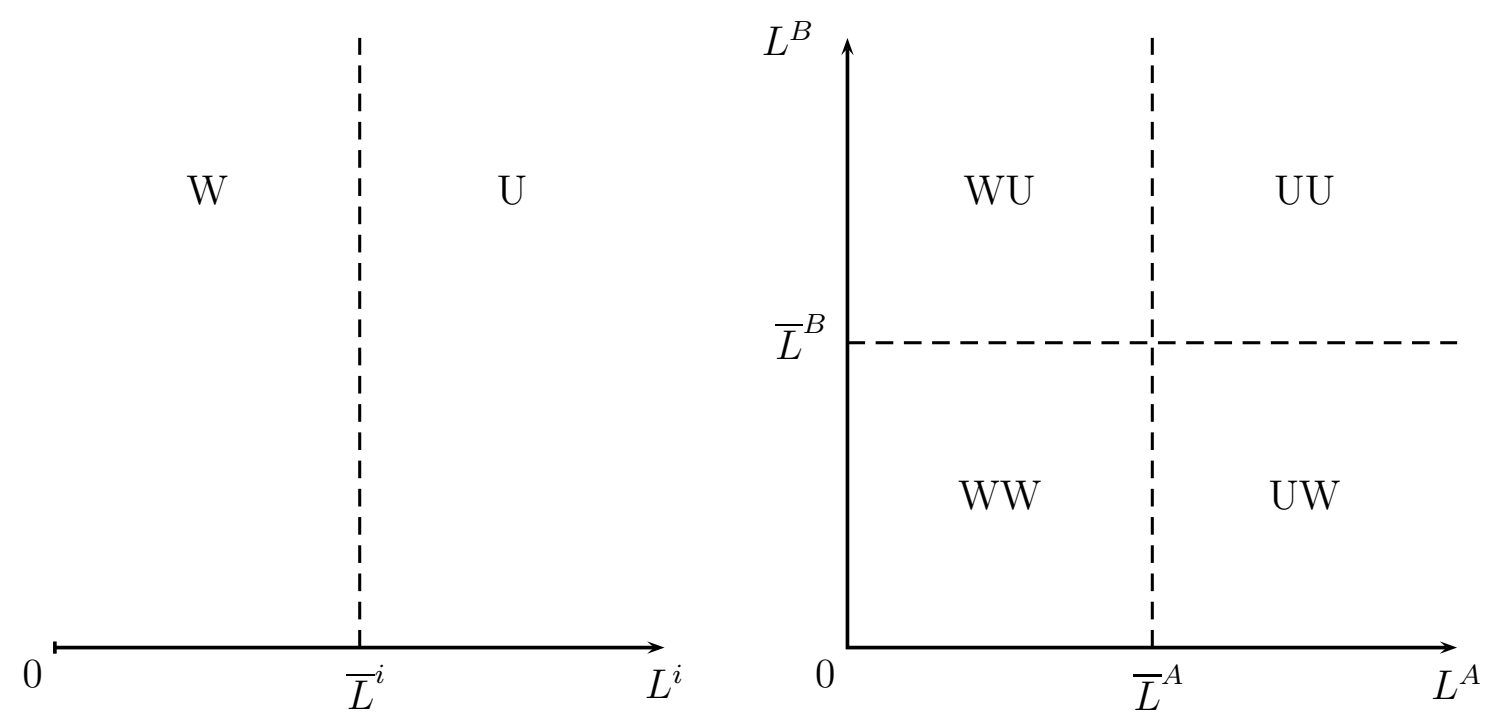

Figure 7: Banks' Capitalization and Equilibria. This figure shows the effect of banks' capitalization on the economy equilibria. The left panel shows the two regions delimited by the threshold $\bar{L}^{i}$ for country $i \in \mathcal{I}$. The right panel maps banks' capitalizations to the equilibria in the economy: capitalization of financial sector $A$ is on the x-axis and capitalization of financial sector $B$ is on the y-axis.

Proposition 3. There exist a threshold $\bar{L}^{i}$ such that banks in $i \in \mathcal{I}$ are undercapitalized if and only if $L^{i}>\bar{L}^{i}$ and well capitalized if and only if $L^{i} \leq \bar{L}^{i}$.

The left panel of Figure 7 shows the two regions identified by the threshold $\bar{L}^{i}$ for a representative country. If the initial level of private debt is greater than the threshold $\left(L>\bar{L}^{i}\right)$, the limited liability constraint binds in the bad state. In this case, banks are undercapitalized and solve (4). Similarly, if the initial level of debt is lower than the threshold $\left(L \leq \bar{L}^{i}\right)$, the limited liability constraint does not bind in the bad state and banks, being well capitalized, solve (2). The right panel of the figure maps the initial private debt level of the two countries to the four regions. The x-axis (y-axis) shows country $A$ (country $B$ ) capitalization and the threshold private debt level. The four regions $U U, U W, W U$, and $W W$ are then easily characterized.

\subsection{Recapitalizations and Welfare}

Having solved the model in the four capitalization regions and discussed how the initial private debt level $L^{i}$ determines in which region a bank is, I now ask which equilibrium (i) is welfare maximizing and which equilibrium do (ii) banks and (iii) government prefer. To build some intuition, I first consider the case where government spending is wasteful and then allow public spending to enter in banks' profits through a lump sum transfer. To make welfare statements, I assume that banks' equity and debt are held by a continuum of domestic households. Since countries are, in each capitalization region, symmetric, there 
is no difference between what is welfare maximizing for countries, individually, and what is welfare maximizing for the entire economy. ${ }^{14}$

Wasteful Spending In this simple framework, having well capitalized banks is always efficient as

$$
\mathbb{E}\left(\Pi\left(k_{W W}\right)\right) \geq \theta \Pi_{H}\left(k_{U U}\right)
$$

where the left hand side is welfare in the $W W$ case and the right and side is the welfare in the $U U$ case. Nevertheless, financial sectors might still prefer the $U U$ equilibrium if the gains from having well capitalized financial banks are lower than the losses shifted to private debt holders in the bad state. Banks prefer to be well capitalized if and only if

$$
\mathbb{E}\left(\Pi\left(k_{W W}\right)\right)-\theta \Pi_{H}\left(k_{U U}\right) \geq L(1-\theta)
$$

where the right hand side is the value of losses shifted to debtholders. The government also faces a trade-off when comparing the two equilibria. Government total expenditure is the sum of $t=0$ debt issuance $D$ and $t=1$ tax collection minus repayment to bondholders. The government prefers to have a well capitalized financial sector if and only if

$$
D_{U U}-D_{W W} \leq(1-\theta) \tau\left(\epsilon_{H}-\epsilon_{L}\right)\left(f\left(k_{W W}\right)-f\left(k_{U U}\right)\right)
$$

where the left hand side is the higher debt issuance in the $U U$ case and the right and side is the higher tax collection in the $W W$ case. Better capitalized banks invest more in the lending technology, boosting tax collection. On the other hand, poorly capitalized banks demand more domestic debt, lowering yields and therefore increasing the equilibrium government debt capacity. In other words, in order to pay lower yields and have a higher debt capacity, a government must bear the cost of crowding-out private lending. ${ }^{15}$

\footnotetext{
${ }^{14}$ This will not be the case in Section 4.2 , where I will characterize some asymmetric equilibria.

${ }^{15}$ The model can accommodate government myopia as in Acharya and Rajan (2013). In such case, government spending is $D+\beta(1-\theta) \tau\left(\epsilon_{H}-\epsilon_{L}\right) f(k)$, where $\beta \in(0,1)$ is the government discount factor. Hence, governments prefer well capitalized domestic banks if and only if $D_{U U}-D_{W W} \leq \beta(1-\theta) \tau\left(\epsilon_{H}-\epsilon_{L}\right)\left(f\left(k_{W W}\right)-\right.$ $\left.f\left(k_{U U}\right)\right)$. Hence, a myopic government is more likely to prefer undercapitalized domestic banks.
} 
Suppose now that governments are in charge of capital regulation, namely they can choose the initial domestic private sector debt level $L$. If the above inequality holds, governments might keep domestic banks undercapitalized so that they optimally act as buyers of last resort for the home public debt.

Corollary 2. (Race-To-The-Bottom) While having well capitalized banks is always efficient, governments prefer to have an undercapitalized domestic financial sector if and only if (7) holds.

Non Wasteful Spending I now relax the assumption of wasteful government spending. This creates a trade-off for the social planner and further links the model to the current European policy debate. ${ }^{16}$ I assume that households get a fraction $\phi \in(0,1)$ of total government spending $G$. In this case, equilibrium quantities and prices are unaffected and it is socially optimal to have well capitalized banks if and only if

$$
\mathbb{E}\left(\Pi\left(k_{W W}\right)\right)-\theta \Pi_{H}\left(k_{U U}\right) \geq \phi\left(G_{U U}-G_{W W}\right)
$$

where $\phi$ is the fiscal multiplier. ${ }^{17}$ Hence, if the fiscal multiplier is $\phi \geq \bar{\phi}$, for some $\bar{\phi}$, it is inefficient to have well capitalized banks. In such case, the higher tax collection originating from a sound financial sector is offset by the benefit of higher government expenditure. In this case, in addition to gains from risk-shifting, banks have another incentive to prefer a high initial private debt level. The government trade-off illustrated in Corollary 2 is unaffected. ${ }^{18}$

\footnotetext{
${ }^{16}$ For a discussion on whether an increase of spending would help the Eurozone, see Blanchard et al. (2014).

${ }^{17}$ New Keynesian models feature a fiscal multiplier between 0.7 and 1. Neoclassical models have a much lower multiplier (see Barro (1981), Ramey (2011), Ilzetzki et al. (2013), Farhi and Werning (2012), and, for a survey, Hall (2009)). When nominal rates are close to the zero lower bound, the multiplier can be close to 2 (see Christiano et al. (2011)).

${ }^{18}$ Alternatively, I can allow the government expenditure $G$ to have a positive impact on productivity (See, for example, Blanchard and Perotti (2002)) and model this channel by making the productivity parameter a function of government spending $G$, with $\tilde{\epsilon}^{i}(G)=\tilde{\epsilon}(G), \tilde{\epsilon}(0)=\epsilon$ and $\frac{\partial \tilde{\epsilon}}{\partial G}>0$. Interestingly, the economy displays now new, and asymmetric, equilibria. To gain intuition, suppose the economy is in the UU region, banks in $S$ invest only domestically, and banks in $I$ invest in both countries. In the baseline economy, such scenario was not an equilibrium as country $S$ did not have enough tax collection to face domestic and foreign demand for its bonds. However, once we allow productivity to depend on government expenditures, country $S$ has high equilibrium government expenditures $G$ that increase the productivity of the domestic financial sector. Tax collection therefore goes up raising the debt capacity to clear markets.
} 


\section{Extensions}

In this section, I discuss the assumptions made in the baseline model and relax them to get additional results.

\subsection{Discussion of Assumptions}

In the interest of tractability, I left private debt holders and price outside the model. This is an important caveat as banks gambling for resurrection shift risk from equity holders to private debt holders. We can think at the latter as depositors protected by an (unmodeled) deposit insurance. ${ }^{19}$ Alternatively, in a world without deposit insurance, private debtholders can be "sleepy" depositors in the spirit of Hanson et al. (2014), that shows how banks liabilities, that are contractually short term, are in reality very stable.

In the baseline model, banks are not allowed to invest in the foreign private lending technology. The next subsection shows that the main results hold as long as banks allocate domestically a sufficiently large share of investment in the private technology. This pattern is observed in data from the Euro periphery: according to BIS, domestic banks accounted, in September 2014, for more than $60 \%$ of total lending to the non-financial sector in the southern peripheral countries. ${ }^{20}$ In the model, a large fraction of lending technology investment allocated domestically ensures that the government defaults, because of scarce tax collection, exactly when the domestic economy is in the bad state. Table C.1 in Appendix C sheds some light, using data on credit risk exposures of major peripheral banks in December 2010, on whether sovereign and banks' defaults are likely to happen at the same time. ${ }^{21}$ The table shows bank-exposure $(i, j)$ pairs where $E A D_{i j}$ is the total credit risk exposure (e.g., including private credit claims) of bank $i$ vis-à-vis country $j$. Peripheral banks are then ranked according to the $E A D_{i j} / E_{i}$ ratio where $E_{i}$ is the market value of equity of bank $i$. Only bank-exposure pairs where $E A D_{i j} / E_{i}>1$ are reported: 13 of the 26 pairs are domestic exposures, i.e. where the country of incorporation of bank $i$ is the same of the country $j$ which the bank is exposed to, suggesting that peripheral banks' credit risk is highly intertwined with the credit risk of the domestic sovereign.

The country-specific shocks are symmetric and uncorrelated in the baseline model. While

\footnotetext{
${ }^{19}$ See, for example, Black et al. (1978) for a discussion of deposit insurance and bank risk-taking.

${ }^{20}$ The data source is the BIS Long Series on Total Credit and Domestic Bank Credit to the Private NonFinancial Sector (publicly available quarterly data). The share of total lending to the private non-financial sector, in September 2014, extended by domestic banks was 68.6\% in Italy, 90.8\% in Greece, 32.1\% in Ireland, $72.6 \%$ in Italy, and $64.4 \%$ in Portugal.

${ }^{21}$ Data is from the December 2010 EBA Stress Test. For details on this dataset, see Appendix B.
} 
identical probabilities $\theta^{i}$ simplify the algebra and isolate the gambling-for-resurrection motive, such simplification comes with a loss of generality. The next subsection solves the model with a riskless country, that, in equilibrium, can sustain a higher debt issuance at lower rates and might attract foreign investors. The model is therefore flexible to also study, for example, the linkages between the core and the periphery in the Eurozone. The solution in the previous section also assumed uncorrelated country-level shocks. This strong assumption is not crucial as the economic channels in the model are robust to non-perfectly correlated country-level shocks. However, in the case where both countries are in the high (low) state at the exact same time, the risk-shifting incentive cease to generate home bias in the government bonds market.

The square-root functional form for the lending technology is assumed without loss of generality so to obtain closed form solutions for prices and isolate the general equilibrium effects of banks' undercapitalization. All the results derived in the previous section still hold with a generic functional form as long as continuous, strictly increasing, strictly concave, and satisfying Inada conditions. Finally, I assumed that $\gamma>1-\theta$ or, equivalently, that the recovery value on government bonds is low enough, i.e. $\lambda<\frac{\epsilon_{L}}{\epsilon_{H}}$. While empirical evidence supports a low recovery value of government bonds compared private debt, the assumption is key in generating the crowding-out effect illustrated in Corollary $1 .^{22}$ In the following subsection, I show that the model, when $\gamma<1-\theta$, presents some equilibria with spillover effects where the undercapitalization of domestic banks affects foreign demand for domestic government bonds.

\subsection{Extensions of the Baseline Model}

In this subsection, I relax the five assumptions illustrated in Section 4. In this more general environment, in addition to the financial autarky equilibria discussed in the baseline model, the economy presents new equilibria where banks' level of capitalization in one country affects the other country.

Relaxing Assumption 1: Foreign Private Lending I now allow banks to invest in domestic and foreign private lending technologies, in addition to the global sovereign bond market. The left panel of Figure 8 shows the investment opportunities of a representative bank in country $i \in \mathcal{I}$. Similar to the baseline model, banks choose how to allocate the

\footnotetext{
${ }^{22}$ According to Moody's (2014), the average value-weighted recovery rate on defaulted government bonds is $26 \%$ compared to $38 \%$ of senior unsecured corporate issuers during the period 1983-2013. Issuer-weighted averages are $49 \%$ and $37 \%$, respectively.
} 


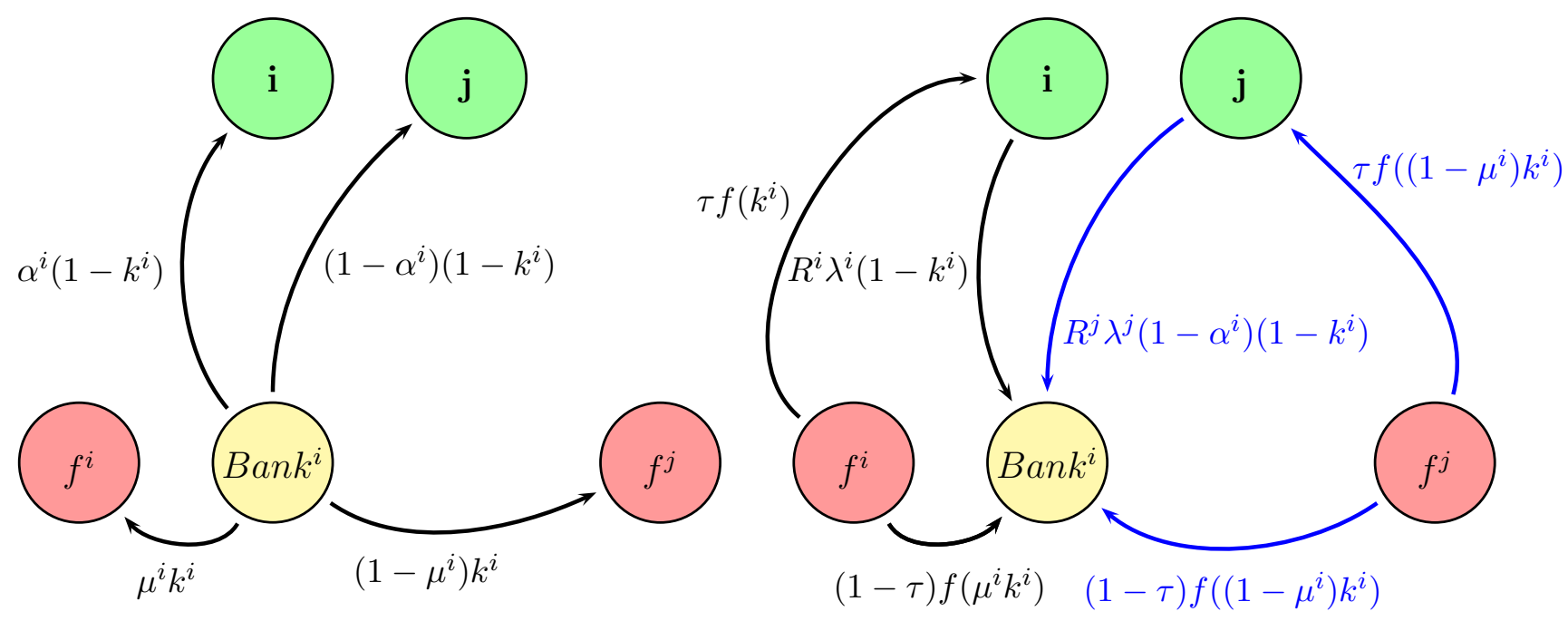

Figure 8: Economy with Access to a Foreign Private Lending. This figure replicates Figure 3 when banks have also access to the foreign private lending technology. The left panel illustrates the investment opportunities of the financial sector in countri $i \in \mathcal{I}$, which can invest in (i) the domestic lending technology $f$, (ii) the foreign lending technology $f^{*}$, (iii) domestic government bonds, and (iv) foreign government bonds. The choice variables $\alpha$ and $\mu$ capture the home bias of the financial sector in the bond market and in the private lending technology, respectively. The right panel shows the payoffs, after they are realized, at $t=1$.

unit endowment between the private lending technology $(k>0)$ and the government bond market $(1-k)$. Moreover, banks now choose, within each asset class, the share that is invested domestically, namely $\mu$ and $\alpha$ for the lending technology and the bond market, respectively. The right panel of the figure shows the payoffs at $t=1$, once uncertainty in both countries is resolved.

The proceeds from investing in private lending are taxed at the exogenous rate $\tau$ and sovereigns use tax collection to repay bondholders. Should tax collection be lower than payments due to bondholders, sovereigns default for liquidity reasons. This can happen in two cases, depending on the share $\mu$ of private lending that is allocated domestically. In the first case, default happens because the home economy is in the bad state and domestic banks have invested a lot in the domestic lending technology (high $\mu$ ). A low realization of domestic private lending has a sizable impact on the tax base and, consequently, on the sovereign ability to repay bondholders: the government is forced to default exactly when banks realize low profits from private lending. This is the mechanism at work in the baseline model as government default is positively correlated with the home state of the world. In the second case, default happens because the foreign economy is in the bad state and domestic banks have invested a lot in the foreign lending technology (low $\mu$ ). Regardless of the domestic state, a low realization of foreign private lending might cause a domestic sovereign default. In other words, a sufficiently low $\mu$ breaks the positive correlation between banks' revenues from private lending and domestic government bonds. With $\mu$ low enough, the 
incentive of undercapitalized banks to gamble for resurrection vanishes. Formally, banks in $i \in \mathcal{I}$ invest domestically if and only if

$$
R^{i} \geq R^{j}\left(1-\mathbf{1}_{U}\left(1-\frac{\mathbb{E}\left(\lambda_{H, s^{j}}^{j}\right)}{\mathbb{E}\left(\lambda_{H, s^{j}}^{i}\right)}\right)\right)
$$

where $\mathbf{1}_{U}$ is an indicator variable equal to one if banks are undercapitalized, $\lambda_{s^{i}, s^{j}}^{i}$ is the recovery value of government $i$ bonds when country $i$ is in $s^{i}$ state and country $j$ is in $s^{j}$ state. Since the two countries are identical, well capitalized banks $\left(\mathbf{1}_{U}=0\right)$ invest domestically if and only if the home interest rate is greater than the foreign interest rate. On the other hand, undercapitalized banks $\left(\mathbf{1}_{U}=1\right)$ have an incentive to tilt their government bond portfolio towards the security that pays the most in the good state. Domestic government serve to this purpose if and only if, in the good home state, their recovery value is higher than the recovery value of foreign government bonds, i.e. if $\mathbb{E}^{j}\left(\lambda_{H, s^{j}}^{j}\right)<\mathbb{E}^{j}\left(\lambda_{H, s^{j}}^{i}\right)$, where expectations are taken with respect to country $j$ probability. If this is the case, undercapitalized banks need to be compensated to hold foreign bonds and the intuition of the baseline model still holds. Perhaps not surprisingly, the condition holds if the correlation between revenues from domestic government bonds and private lending technology is high enough. Such correlation, in turn, depends, as discussed, on the choice variable $\mu .^{23}$

Relaxing Assumption 2: Correlated Shocks I now assume that the two countryspecific shocks are correlated, with $\operatorname{corr}\left(\epsilon^{A}, \epsilon^{B}\right)=\rho$. Keeping the marginal probabilities unchanged in both countries, I can compute the following joint probabilities:

$$
\begin{aligned}
& \operatorname{Prob}\left(s^{A}=H \cap s^{B}=H\right)=\theta(1-(1-\rho)(1-\theta)) \\
& \operatorname{Prob}\left(s^{A}=H \cap s^{B}=L\right)=(1-\rho) \theta(1-\theta) \\
& \operatorname{Prob}\left(s^{A}=L \cap s^{B}=L\right)=(1-\theta)(\rho+(1-\rho)(1-\theta))
\end{aligned}
$$

where $s^{i} \in \mathcal{S}$ is the state of the world of country $i \in \mathcal{I}$ and $\operatorname{Prob}\left(s^{A}=H \cap s^{B}=L\right)=$ $\operatorname{Prob}\left(s^{A}=L \cap s^{B}=H\right)$ by symmetry. Lemma 1 still holds as governments default in the bad state only, when the tax base is not sufficient to repay bondholders.

\footnotetext{
${ }^{23}$ Appendix A.2 derives the conditions needed for banks to have the gambling-for-resurrection incentive.
} 
Note that in the $W W$ case, where both financial sector are well capitalized, only marginal probabilities matter and the economy is therefore identical to the one developed in baseline model. In particular, financial sectors invest in the domestic government bond market if and only if $R \geq R^{*}$. Nevertheless, the non-zero correlation affects the portfolio choice of undercapitalized banks. Because of the binding limited liability constraint, these make investment decisions to maximize the payoff in the good state of the world. Here, the domestic government never defaults and bondholders get the high payoff $R$. The payoff, in the good domestic state, of foreign government bonds crucially depends on the correlation coefficient. In case $\rho<1$, the foreign government might default in the domestic high state, introducing the home bias discussed in the baseline model. However, if $\rho=1$, the two governments always default at the same time and banks' problem is therefore unchanged from the $W W$ case. For a generic $\rho \in[-1,1)$, undercapitalized banks invest domestically if and only if

$$
R \geq(1-(1-\rho)(1-\lambda)(1-\theta)) R^{*}
$$

where the term in parentheses is the required compensation needed by domestic undercapitalized banks to hold foreign government bonds.

Relaxing Assumption 3: One Safe Country, One Risky Country I now assume that the lending technology is risky in country $A\left(\theta^{A} \in(0,1)\right)$ and riskless in country $B\left(\theta^{B}=1\right)$. The problem faced by banks in $A$ is unchanged from the baseline model: Lemma 1 holds and the government is forced to default on part of its debt in the bad state. On the other hand, as there is no uncertainty, the government in $B$ has always enough tax collection at $t=1$ to repay bondholders. In order to isolate the effect of the different shock probabilities on the government bond market, I normalize country $B$ production function so that banks in the two countries get, in expectation, the same payoff from private lending. ${ }^{24}$

Note that there are only two states in the economy: the benchmark state where both financial sectors are well capitalized $(W W)$ and the state where banks in $A$ are undercapitalized and banks in $B$ are well capitalized $(U W) .{ }^{25}$ As in the baseline model, when both

\footnotetext{
${ }^{24}$ Formally, $\Delta^{i}=\mathbb{E}^{A}(\epsilon)-\gamma \epsilon_{L} \theta^{A}$ for $i \in \mathcal{I}$. In other words, (i) an investment of $k^{B}$ in country $B$ private lending technology yields $(1-\tau) \Delta_{\epsilon} f\left(k^{B}\right)$ with certainty at $t=1$ and (ii) an investment of $k^{A}$ in country $A$ private lending technology yields $(1-\tau) \Delta_{\epsilon} f\left(k^{A}\right)$ in expectation at $t=1$.

${ }^{25}$ Banks in $B$ can only be well capitalized as their limited liability constraint never binds. As in Section 3.5 , I do not study the trivial case where the limited liability binds in every state of the world at $t=1$.
} 


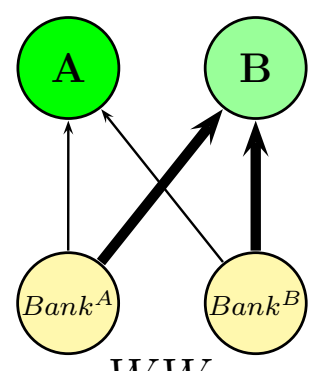

$W W$

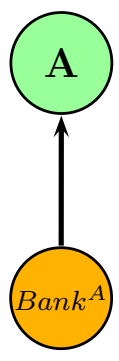

$U W$

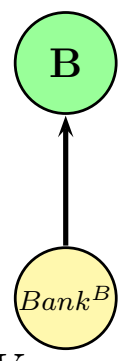

$$
\text { (l) }
$$

Figure 9: One Risky Country and One Safe Country. The left panel of this figure shows the equilibria in an economy where country $A$ is risky $\left(\theta^{A} \in(0,1)\right)$ and country $B$ is riskless $\left(\theta^{B}=1\right)$. The left panel shows the equilibria in the $W W$ case and the right panel shows the unique equilibrium in the $U W$ case. Orange banks are undercapitalized and yellow banks are well capitalized.

countries have well capitalized banks, there is perfect risk-sharing in equilibrium with financial sectors investing in both sovereigns. Yields are such that

$$
\mathbb{E}^{A}\left(\lambda^{A}\right) R^{A}=R^{B}
$$

where superscripts refer to countries. The risk-adjusted return on government bonds in the two countries must be equal so that the risky country $A$ needs to pay its bondholders more than country $B$ to remunerate them for the higher credit risk. Higher government yields in $A$ reduce the government debt capacity. In equilibrium, the riskless country has higher debt capacity and attracts foreign investors, as shown by the left panel of Figure 9.

Suppose now that banks in $A$ are undercapitalized. The unique equilibrium is illustrated in the right panel of the figure. As in the baseline model, undercapitalization of one financial sector generates financial autarky in the whole economy with both sovereigns facing only domestic demand for their bonds. The riskless country still enjoys a higher debt capacity and pays lower yields compared to the risky country.

Relaxing Assumption 4: Lending Technology with General Functional Form All the results obtained in the previous section still holds with a generic functional functional form for the lending technology. However, closed-form solutions cannot be obtained as market clearing conditions in an autarky equilibrium are

$$
1-k(R)=\tau f(k(R)) \Delta_{\epsilon} R^{-1}
$$

Relaxing Assumption 5: $\gamma<1-\theta$ I now assume that the recovery value of government bonds in the bad state is sufficiently high, namely $\gamma<1-\theta$ or $\lambda>\epsilon_{L}\left(\epsilon_{H}\right)^{-1}$. Compared to the baseline model, the $W W$ equilibrium still features perfect risk sharing with both governments facing, at the same interest rate, foreign and domestic demand for their bonds. 

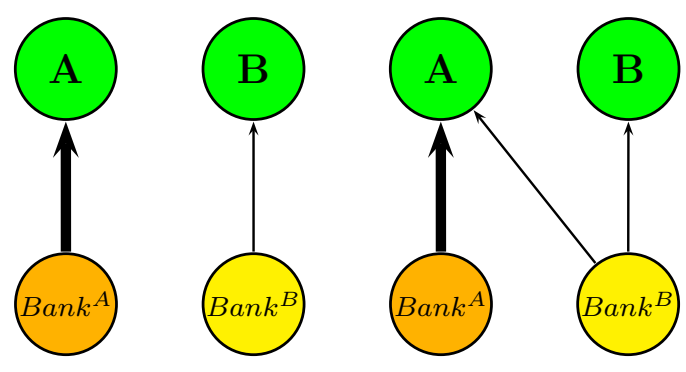

Figure 10: Two UW Equilibria $(\gamma<1-\theta$ case). This figure illustrates the two equilibria in the UW region when $\gamma<1-\theta$. The left panel shows the financial autarky equilibrium and the right panel shows the asymmetric equilibrium. Orange banks are undercapitalized and yellow banks are well capitalized.

As the recovery value on government bonds $\lambda$ increases (lower $\gamma$ ), banks invest more in the relatively safer government bonds reducing private lending. Similarly, the $U U$ equilibrium is unchanged from the baseline model.

However, in the the case where one financial sector is well capitalized and one financial sector is undercapitalized, the economy now has two equilibria, as shown in Figure 10 for the $U W$ case. The left panel illustrates the standard autarky equilibrium where the binding limited liability induces undercapitalized banks in $A$ to tilt their government bond portfolio toward domestic securities. However, banks now invest more in the private lending technology and less in the government bond market compared to the $W W$ case. Seeking higher payoff volatility, banks choose private lending as a tool to risk-shift, as domestic government bonds are too safe for this purpose $\left(\lambda>\epsilon_{H}\left(\epsilon_{L}\right)^{-1}\right)$. The government tax collection therefore increases driven by a higher tax base. In equilibrium, the lower demand for bonds causes interest rates to increase. The government has lower debt capacity and faces high interest rates.

In addition to the standard autarky equilibrium, the economy can fall in an asymmetric equilibrium where $A$ faces both foreign and domestic demand for its bonds, illustrated in the right panel of the figure. Sovereign $A$ attracts foreign investors by offering them a high interest rate, which can be sustained by the high domestic tax base. Interestingly, because of poorly capitalized foreign banks, country $B$ pays high interest rate and has lower debt capacity, compared to the $W W$ case. In particular

$$
R_{U W, a s y}=\left(\left(R_{W W}\right)^{2}+\left(R_{U U}\right)^{2}\right)^{1 / 2}
$$

\section{Supporting Empirical Evidence}

This section provides supporting empirical evidence for the mechanism proposed in the model. I document that worse-capitalized banks increased the relative holdings of domestic 
sovereign debt compared to better capitalized banks during the Euro crisis. Moreover, I show that banks with revenues originating mainly from domestic activities ("local" banks) also engaged in a similar behavior compared to banks with more revenues originating abroad ("international" banks). In the remainder of this section I describe the dataset, show correlations consistent with the proposed channel, and discuss potential alternative explanations.

Data and Summary Statistics I construct a dataset using the European Banking Authority (EBA) stress tests data and Bankscope. ${ }^{26}$ The EBA conducted eight stress tests between October 2009 and June 2013 in order to "ensure the orderly functioning and integrity of financial markets and the stability of the financial system in the EU". With the exception of the first stress test, the Authority disclosed data on "Gross Direct Long Exposures" of a sample of systemically important European banks. ${ }^{27}$ I merge the EBA sample with Bankscope to obtain data on banks' characteristcs. Table B.2 in the Appendix shows the full list of EBA banks and the sample used in the analysis. I discard banks with three or less EBA observations and the four Greek banks that participated at the first two and last two stress tests only. The final sample consists of a panel of 61 banks from 20 countries. The dataset comprises exposures of each bank vis-à-vis 30 sovereigns. Table 1 shows summary statistics for the entire sample, as well as subsamples of peripheral and core banks. ${ }^{28}$ The top panel shows total exposures to total, domestic, peripheral (GIIPS), and core government bonds in tn $€$. Two differences between core and peripheral banks stand out from the table. First, peripheral banks increased their holdings of domestic public debt from $€ 0.32$ tn in March 2010 to $€ 0.47$ tn in June 2013, driving the growth of total government bond holdings from $€ 0.39$ tn to $€ 0.57$ tn during the same period. Findings are consistent with Crosignani et al. (2015), that documents a seven-fold increase of domestic government bonds by Portuguese banks during the crisis. During the same period holdings of domestic bonds by core banks are approximately constant, rising only by $10 \%$ at the end of the sample. Second, core banks halved their holdings of risky GIIPS debt from $€ 0.25$ tn in March 2010 to $€ 0.12$ tn in June 2013. On the other hand, driven by domestic bonds, peripheral banks' exposure to risky debt increased from $€ 0.32$ tn to $€ 0.47 \mathrm{tn}$. The bottom panel shows crosssectional averages of assets, tier 1 ratio, leverage, risk weighted assets, and short term debt.

\footnotetext{
${ }^{26}$ Appendix B describes the dataset and its construction in great detail. Data and code are publicly available on my webpage.

${ }^{27}$ Gross Direct Long Exposures are the "direct debt exposures to central and local governments."

${ }^{28}$ GIIPS banks are headquarted in Italy, Spain, Portugal, and Ireland. Greek banks are dropped from the sample since they we excluded from three consecutive stress tests. Core banks are headquartered in Austria, Belgium, Germany, France, and Netherlands.
} 


\section{Mar10 Dec10 Sep11 Dec11 Jun12 Dec12 Jun13}

\begin{tabular}{lccccccc}
\hline \multicolumn{7}{c}{ Peripheral Banks } \\
\hline Total & 0.39 & 0.42 & 0.42 & 0.40 & 0.46 & 0.50 & 0.57 \\
Domestic & 0.29 & 0.34 & 0.33 & 0.32 & 0.37 & 0.40 & 0.45 \\
GIIPS & 0.32 & 0.36 & 0.35 & 0.33 & 0.39 & 0.41 & 0.47 \\
Core & 0.04 & 0.03 & 0.03 & 0.04 & 0.04 & 0.06 & 0.06 \\
\hline \multicolumn{7}{c}{ Core Banks } \\
\hline Total & 1.03 & 0.99 & 0.94 & 0.87 & 0.92 & 0.96 & 0.97 \\
Domestic & 0.50 & 0.49 & 0.49 & 0.48 & 0.52 & 0.55 & 0.55 \\
GIIPS & 0.25 & 0.17 & 0.14 & 0.12 & 0.11 & 0.11 & 0.12 \\
Core & 0.65 & 0.70 & 0.70 & 0.65 & 0.71 & 0.75 & 0.75 \\
\hline
\end{tabular}

$2010 \quad 2011 \quad 2012 \quad 2013$

\begin{tabular}{|c|c|c|c|c|}
\hline \multicolumn{5}{|c|}{ Peripheral Banks } \\
\hline Total Assets & 459.6 & 419.8 & 406.0 & 425.1 \\
\hline Tier 1 Ratio & 8.7 & 8.9 & 11.2 & 12.1 \\
\hline Leverage & 7.1 & 6.4 & 6.3 & 6.6 \\
\hline RWA & 255.7 & 224.4 & 209.4 & 201.8 \\
\hline ST Debt & 257.3 & 238.6 & 234.6 & 248.3 \\
\hline \multicolumn{5}{|c|}{ Core Banks } \\
\hline Total Assets & 770.0 & 790.7 & 767.1 & 749.8 \\
\hline Tier 1 Ratio & 10.1 & 12.7 & 12.3 & 13.6 \\
\hline Leverage & 3.6 & 4.0 & 3.8 & 4.1 \\
\hline RWA & 243.1 & 238.3 & 218.7 & 211.7 \\
\hline ST Debt & 409.7 & 416.0 & 380.3 & 387.5 \\
\hline
\end{tabular}

Table 1: Summary Statistics. Bond Holdings and Balance Sheet Characteristics. These tables present summary statistics. The top panel shows total exposure of peripheral (Ireland, Italy, Spain, and Portugal) and core (Austria, Belgium, Germany, France, and Netherlands) banks vis-à-vis total, domestic, GIIPS, and core government bonds. Dates correspond to the EBA stress test dates and quantities are in tn $€$. The bottom panel shows average total assets, tier 1 ratio, leverage, risk weighted assets, short term debt for the two same subsamples from 2010 to 2013. Total assets, risk weighted assets, and short term debt are in bn $€$. The source is Bankscope. 
Core banks are in average larger and better capitalized compared to peripheral banks.

Risk-shifting and Domestic Government Bond Holdings I now show evidence consistent with the risk-shifting motive. The model has two clear empirical predictions: (i) worse-capitalized banks (in the $W$ region) increase their holdings of government bonds compared to better capitalized banks (in the $U$ region) and (ii) geographically undiversified banks (high $\mu$ ) increase their holdings of government bonds compared to more geographically diversified banks (low $\mu$ ). First, I measure capitalization with book leverage, defined as assets divided by book value of equity, in 2010. Taking advantage of the heterogeneity in leverage at the beginning of the sample, I divide peripheral banks in the top and bottom quartile according to the level of leverage. The left panel of Figure 11 shows the evolution of home bias, defined as domestic government bonds divided by total assets and normalized to 100 in March 2010, during the sample period. From March 2010 to June 2013, the home bias of high leverage and low leverage banks increased by $115 \%$ and $55 \%$, respectively. Second, I measure geographical diversification using the Exposure at Default (EAD) to the domestic economy divided by assets in December 2010. The third EBA stress test released the banklevel EAD, that measures the total bank credit risk exposure vis-à-vis various countries. This statistics is not limited to public debt and includes exposures to residential and commercial real estate, corporations, and institutions. I define "local" and "international" banks in the top and lower quartile according to the exposure at domestic default. The right panel of the figure shows that local banks increased their holdings of domestic government bonds by $40 \%$ more compared to international banks during the sample period.

Alternative Explanations I now discuss five alternative explanations for the accumulation of domestic government bonds on the balance sheet of peripheral banks. These are (i) regulatory arbitrage, (ii) moral suasion, (iii) redenomination risk, (iv) voluntary "financial entanglement", and (v) information advantage.

Many commentators attributed the increased domestic government bond holdings to their zero capital requirement. In fact, risk weights for Euro denominated government bonds is zero, making peripheral public debt a cheap way to buy risky securities and improve regulatory capital ratios. ${ }^{29}$ However, the empirical evidence from stress test data is inconsistent with this motive as, under the regulatory arbitrage hypothesis, peripheral banks seeking to

\footnotetext{
${ }^{29}$ Under the Capital Requirement Directive (CRD), "exposures to Member States' central governments and central banks denominated and funded in the domestic currency of that central government and central bank shall be assigned a risk weight of 0\%." (Directive 2006/48/EC, Annex VI, Part 1(4)). For a discussion of the zero capital requirements regime in Europe, see Korte and Steffen (2014).
} 
Domestic Government Bonds and

Leverage

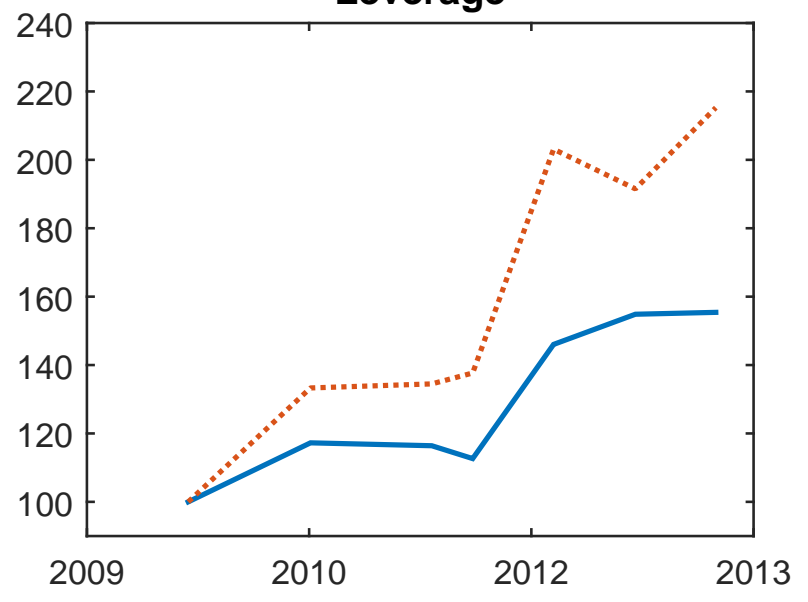

Low Leverage n........ High Leverage
Domestic Government Bonds and International Credit Exposure

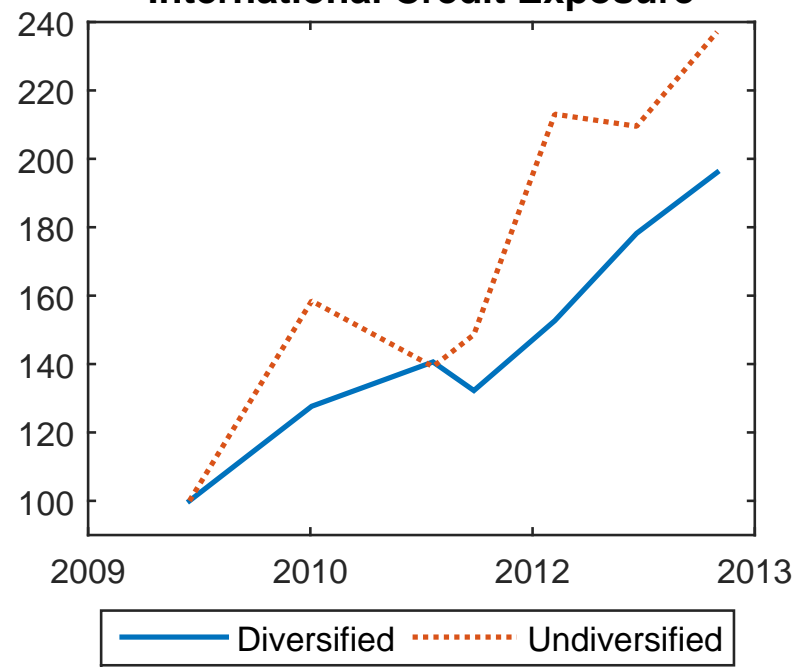

Figure 11: Risk-shifting and Home Bias. This figure shows the evolution of home bias (normalized at 100 in 2010Q1) of GIIPS banks from 2010Q1 to 2013Q2. Home bias is defined as exposure to domestic government debt divided by total exposure to government debt. The left panel illustrates the evolution of home bias for high leverage (red dashed line) and low leverage (solid blue line) banks. Leverage is book value of equity divided by total assets. High leverage banks and low leverage banks are respectively the top and bottom quartile of banks ordered by leverage. The right panel illustrates the increase in home bias for geographically undiversified (red dashed line) and geographically diversified (solid blue line) banks. Geographical diversification is the Total Exposure at Default (EAD) to foreign countries divided by total assets as of 2010Q4. EAD is from the 2011 EBA Stress Test. "Local" and "International" banks are respectively the top and bottom quartile of banks ordered by domestic EAD divided by Assets. Source: Bankscope, European Banking Authority.

buy risky securities should be indifferent between domestic bonds and GIIPS-non-domestic bonds. However, holdings of GIIPS-non-domestic bonds by peripheral banks dropped between March 2010 and June 2013.

Under the moral suasion hypothesis, governments force domestic financial institutions to buy more domestic bonds when yields are high and demand for domestic public debt is low (see Bo and Ivashina (2014), De Marco and Macchiavelli (2014)). In exchange, governments might promise, for example, a more tolerant supervision. The evidence in this section is consistent with moral suasion as long as the government financial repression is more effective with high leverage banks. According to the model presented in this paper, this might be the case as the government is likely to be more successful in repressing those banks that, for a risk-shifting motive, already have an incentive to buy more domestic debt.

An additional motive that may drive bank behavior is the emergence of redenomination risk, namely the risk that foreign sovereign debt might be redenominated in the foreign currency in case of an Euro breakup. This channel is both difficult to isolate and ambiguous in its implications. In particular, it is not clear whether redenomiation risk would make 
foreign debt more or less attractive. For example, in case of Euro breakup, a peripheral bank might be better off with foreign, say German, government bonds as it would benefit from the hypothetical currency appreciation. ${ }^{30}$

Under the voluntary "financial entanglement" hypothesis, weak banks are optimally buying more domestic government bonds so that the government is more likely to bail them out in case of default, in order to prevent a costly fire sale of their government bond portfolio. My findings are consistent as long as both high leverage and geographically undiversified banks are engaging in this behavior.

Under the information advantage hypothesis, domestic investors have a higher ability to process information regarding the home sovereign and such advantage increases during crises. ${ }^{31}$ If the greater ability to process information is positively correlated with leverage and negatively correlated with geographical diversification, the empirical findings are consistent.

\section{Conclusion}

Financial sectors in Greece, Italy, Ireland, Portugal, and Spain experienced an increasing home bias in government debt as sovereigns became riskier. I propose a model where highly leveraged banks invest in domestic bonds because of the high correlation with their other sources of revenues. Protected by limited liability, banks cut lending to invest in the relatively more attractive domestic sovereign debt. Anticipating this mechanism, governments may set low capital requirements to encourage risk-shifting, increasing their debt capacity, when they most need to borrow. Governments may also trigger a "race to the bottom" in capital regulation, bearing the cost distortion in the respective lending markets. The model can rationalize, in the context of the Euro crisis, the increasing demand for domestic government bonds in the periphery, the crowding out effect in private lending, and the hesitancy to recapitalize the financial sector. While I am unable to disentangle the different channels in play, recent EBA stress test data support the proposed risk-shifting hypothesis as undercapitalized banks have driven the purchases of domestic bonds.

\footnotetext{
${ }^{30}$ Related to this channel is Corradin and Rodriguez-Moreno (2015) that shows how Eurozone USDdenominated sovereign bonds became substantially cheaper than euro-denominated bonds during the eurozone crisis. The authors ascribe the mispricing to eligibility as collateral at the European Central bank of Euro donominated bonds only.

${ }^{31}$ The role of information and home bias has been studied, among others, by Coval and Moskowitz (1999) and Coval and Moskowitz (2011).
} 


\section{References}

Acharya, V., T. Eisert, C. Eufinger, and C. Hirsch (2014a): "Real Effects of the Sovereign Debt Crisis in Europe: Evidence from Syndicated Loans," Working Paper.

Acharya, V. and R. G. Rajan (2013): "Sovereign Debt, Government Myopia, and the Financial Sector," Review of Financial Studies, 26, 1526-1560.

Acharya, V. and S. Steffen (forthcoming): "The Greatest Carry Trade Ever? Understanding Eurozone Bank Risks," Journal of Financial Economics.

Acharya, V. V., I. Drechsler, and P. Schnabl (forthcoming): "A Pyrrhic Victory? Bank Bailouts and Sovereign Credit Risk," Journal of Finance.

Acharya, V. V., R. Engle, and D. Pierret (2014b): "Testing Macroprudential Stress Tests: The Risk of Regulatory Risk Weights," Carnegie-Rochester Public Policy Conference Volume of the Journal of Monetary Economics, 65, 36-53.

Almeida, H., I. Cunha, M. Ferreira, And F. Restrepo (2014): "The Real Effects of Credit Ratings: The Sovereign Ceiling Channel," Working Paper.

Arslanalp, S. And T. Tsuda (2012): "Tracking Global Demand for Advanced Economy Sovereign Debt," Working Paper.

Barro, R. (1981): "Output Effects of Government Purchases," Journal of Political Economy, 89, 1086-1121.

Begenau, J. (2015): "Capital Requirements, Risk Choice, and Liquidity Provision in a Business Cycle Model," Working Paper.

Black, F., M. H. Miller, and R. A. Posner (1978): "An Approach to the Regulation of Bank Holding Companies," Journal of Business, 51, 379-412.

Blanchard, O., C. Erceg, and J. Linde (2014): "Jump-Starting the Euro Area Recovery: Would a Rise in Core Fiscal Spending Help the Periphery?" Working Paper.

Blanchard, O. And R. Perotti (2002): "An Empirical Characterization of the Dynamic Effects of Changes in Government Spending and Taxes on Output," Quarterly Journal of Economics, 117, 1329-1368.

Bo, B. And V. Ivashina (2014): "Financial Repression in the European Sovereign Debt Crisis," Working Paper.

(forthcoming): "Reaching for Yield in the Bond Market," Journal of Finance. 
Bocola, L. (2013): "The Pass-Through of Sovereign Risk," Working Paper.

Bofondi, M., L. Carpinelli, And E. Sette (2013): "Credit Supply During a Sovereign Debt Crisis," Working Paper.

Boz, E., P. D'Erasmo, And C. B. Durdu (2014): "Sovereign Risk and Bank Balance Sheets: The Role of Macroprudential Policies," Working Paper.

Broner, F., , A. Martin, and J. Ventura (2010): "Sovereign Risk and Secondary Markets," American Economic Review, 100, 1523-1555.

Brunnermeier, M. K. (2015): "Diabolic Loop between Sovereign and Banking Risk," G7 Bundesbank and BMF Panel Discussion.

Brutti, F. And P. Saure (2013): "Transmission of Sovereign Risk in the Euro Crisis," Working Paper.

Buch, C. M., M. Koetter, And J. Ohls (2013): "Banks and Sovereign Risk: a Granular View," Working Paper.

Caballero, R. J., T. Hoshi, and A. K. Kashyap (2008): "Zombie Lending and Depressed Restructuring in Japan," American Economic Review, 98, 1943-1977.

Chari, V., A. Dovis, and P. J. Kehoe (2015): "On the Optimality of Financial Repression," Working Paper.

Chodorow-Reich, G. (2014): "The Employment Effects of Credit Market Disruptions: Firm-Level Evidence from the 2008-09 Financial Crisis," Quarterly Journal of Economics, 129, 1-59.

Christiano, L., M. Eichenbaum, and S. Rebelo (2011): "When Is the Government Spending Multiplier Large?" Journal of Political Economy, 119, 78-121.

Corradin, S. and M. Rodriguez-Moreno (2015): "Limits to Arbitrage: Empirical Evidence from Euro Area Sovereign Bond Markets," Working Paper.

Coval, J. D. And T. J. Moskowitz (1999): "Home Bias at Home: Local Equity Preference in Domestic Portfolios," Journal of Finance, 54, 2045-73.

_ (2011): "The Geography of Investment: Informed Trading and Asset Prices," Journal of Political Economy, 109, 811-41.

Crosignani, M., M. Faria-e Castro, and L. Fonseca (2015): "Central Bank Interventions, Demand for Collateral, and Sovereign Borrowing Costs," Working Paper. 
De Marco, F. (2014): "Bank Lending and the Sovereign Debt Crisis," Working Paper.

De Marco, F. And M. Macchiavelli (2014): "The Political Origin of Home Bias: the Case of Europe," Working Paper.

Diamond, D. W. And R. G. Rajan (2011): "Fear of Fire Sales, Illiquidity Seeking, and Credit Freezes," The Quarterly Journal of Economics, 126, 557-591.

Drechsler, I., T. Drechsel, D. Marques-Ibanez, and P. Schnabl (2014): "Who Borrows from the Lender of Last Resort?" Working Paper.

European Commission (2011): "CRD IV - Frequently Asked Questions," Press Release Database, Memo/11/527.

Farhi, E. And J. Tirole (2014): "Deadly Embrace: Sovereign and Financial Balance Sheets Doom Loops," Working Paper.

Farhi, E. And I. Werning (2012): "Fiscal Multipliers: Liquidity Trap and Currency Unions," Working Paper.

Gennaioli, N., A. Martin, And S. Rossi (2012): "Sovereign Default, Domestic Banks, and Financial Institutions," Working Paper.

- (2014): "Banks, Government Bonds, and Default: What Do the Data Say?" Working Paper.

Giannetti, M. And A. Simonov (2013): "On the Real Effects of Bank Bailouts: Micro Evidence from Japan," American Economic Journal: Macroeconomics, 5, 125-167.

Greenlaw, D., A. K. Kashyap, K. L. Schoenholtz, and H. S. Shin (2012): "Stressed Out: Macroprudential Principles for Stress Testing," Working Paper.

Hall, R. (2009): "By How Much Does GDP Rise If the Government Buys More Output?" Brookings Papers Econ. Activity, 2, 183-231.

Hanson, S. G., A. Shleifer, J. C. Stein, And R. W. Bishny (2014): "Banks as Patient Fixed-Income Investors," Working Paper.

Hildebrand, T., J. Rocholl, And A. Schulz (2012): "Flight to Where? Evidence from Bank Investments During the Financial Crisis," Working Paper.

Homar, T. (2014): "Bank Recapitalizations and Lending: A Little is Not Enough," Working Paper. 
Ilzetzki, E., E. Mendoza, And C. A. Vegh (2013): "How Big (Small?) Are Fiscal Multipliers," Journal of Monetary Economics, 60, 239-254.

Ivashina, V. And D. Scharfstein (2010): "Loan Syndication and Credit Cycles," American Economic Review, 100, 57-61.

Jensen, M. C. And W. H. Meckling (1976): "Theory of the Firm: Managerial Behavior, Agency Costs and Ownership Structure," Journal of Financial Economics, 3, 305-360.

Korte, J. And S. Steffen (2014): "Zero Risk Contagion - Banks' Sovereign Exposure and Sovereign Risk Spillovers," Working Paper.

Moody's (2014): "Sovereign Default and Recovery Rates, 1983-2013," Moody's Global Credit Policy.

Perez, D. (2014): "Sovereign Debt, Domestic Banks and the Provision of Public Liquidity," Working Paper.

Philippon, T. And P. Schnabl (2013): "Efficient Recapitalization," Journal of Finance, $68,1-42$.

Popov, A. A. And N. Van Horen (2013): "The Impact of Sovereign Debt Exposure on Bank Lending: Evidence from the European Debt Crisis," Working Paper.

Ramey, V. A. (2011): "Identifying Government Spending Shocks: Its All in the Timing," Quarterly Journal of Economics, 126, 1-50.

Reinhart, C. And M. B. Sbrancia (forthcoming): "The Liquidation of Government Debt," Economic Policy.

Santos, J. (forthcoming): "Bank Loan Pricing Following the Subprime Crisis," Review of Financial Studies.

Uhlig, H. (2013): "Sovereign Default Risk and Banks in a Monetary Union," German Economic Review, 15, 23-41. 


\section{Appendix}

\section{A Derivations and Proofs}

This Section is devoted to derivations and proofs. Superscripts indicate countries and Figure A.1 illustrates the nine possible banks-sovereign "arrangements" in the economy.

\section{A.1 Baseline Model}

Proof of Lemma 1. Using (3) the payment due to bondholders at $t=1$ is

$$
D R=\Delta_{\epsilon} \tau f(k)
$$

In the good state $(s=H)$, tax collection (minus non-discretionary expenditure $g$ ) is greater than payments due to bondholders if and only if

$$
\begin{aligned}
\tau f(k)\left(\epsilon_{H}-\gamma \epsilon_{L}\right) & >\Delta_{\epsilon} \tau f(k) \\
\epsilon_{H} & >\mathbb{E}(\epsilon)
\end{aligned}
$$

Hence, in the good state, the government is always able to fully repay bondholders. In the bad state $(s=L)$ ), tax collection (minus non-discretionary expenditure $g$ ) is greater than payments due to bondholders if and only if

$$
\begin{aligned}
\tau f(k) \epsilon_{L}(1-\gamma) & >\Delta_{\epsilon} \tau f(k) \\
0 & >\theta\left(\epsilon_{H}-\epsilon_{L}\right)
\end{aligned}
$$

Hence, in the bad state the government always defaults on part of its debt. The haircut $\lambda$ is the parameter such that tax collection equals the post-haircut payments due to bondholders

$$
\begin{aligned}
\tau \epsilon_{L} f(k)-g & =\lambda D R \\
\lambda_{L} & =\epsilon_{L}(1-\gamma) \Delta_{\epsilon}^{-1}
\end{aligned}
$$

Proof of Proposition 1. From the maximization problem of the banking sector we get

$$
\begin{aligned}
k & =f^{\prime-1}\left(\frac{\mathbb{E}(\lambda)\left(\alpha R+(1-\alpha) R^{*}\right)}{\mathbb{E}(\epsilon)(1-\tau)}\right) \\
k_{L L} & =f^{\prime-1}\left(\frac{\left(\alpha R+\mathbb{E}(\lambda)(1-\alpha) R^{*}\right)}{\epsilon_{H}(1-\tau)}\right)
\end{aligned}
$$

where the subscript $L L$ indicates that the limited liability constraint binds in the bad state, i.e. the banking sector solves (4).

First, I show that arrangements (h) and (i) are not candidate equilibria. Consider arrangement (h) where both banks invest in $B$. Market clearing for country $A$ is violated as $k^{A}>0$ (Inada condition). Second, I show that arrangements (e) and (f) are not candidate equilibria. Consider arrangement (e) where $A$ banks invest only abroad and $B$ banks invest in both sovereign bonds. It is 
immediate to show that $R^{B}=R^{A}$ and $k^{B}=k^{A}$. We then reach a contradiction since governments face different demand for bonds, having the same debt capacity in equilibrium. Third, I show that arrangements (c) and (d) are not candidate equilibria. Consider arrangement (c). Since, $A$ banks invest in both countries, it must be that $R^{B}=R^{A}$ and $k^{B}=k^{A}$. We then reach a contradiction since governments have the same debt capacity, but face different demands, in equilibrium. Fourth, we need to rule out the degenerate arrangements where one banking sector does not hold any government bonds, hence investing $k=1$ in the lending technology. Suppose $k^{A}=1$. If financial sector $B$ invests in both types of government bonds, it must be that $R^{A}=R^{B}$. Hence, $k^{B}=1$ reaching a contradiction, as both governments have a strictly positive debt capacity. Suppose country $A$ faces zero demand for its bonds. In equilibrium, it must be that $R^{A}=\infty$ and $R^{B}=\infty$ since $R^{B} \geq R^{A}$. In that case country $B$ has zero debt capacity too. Finally, suppose that country $B$ faces no demand for its bonds. Similar to the case where $A$ face no demand for its bonds, we reach a contradiction as both interest rates are infinite. I now show that in equilibrium the two financial sectors must have the same home bias $\left(\alpha^{i}=\alpha\right.$, for $\left.i=A, B\right)$. In each of the three candidate arrangements (a), (b), (g), it must be that $R^{B}=R^{A}$ and $k^{B}=k^{A}$. Countries in arrangements (b) and $(\mathrm{g})$ have therefore the same home bias. I need to show that countries have the same home bias also in arrangement (a). Market clearing conditions can be written as $\left(\alpha^{A}+1-\alpha^{B}\right)(1-k)=D^{A}$ and $\left(\alpha^{B}+1-\alpha^{A}\right)(1-k)=D^{B}$. We reach a contradiction unless $\alpha^{A}=\alpha^{B}$.

Closed-Form Solutions. Having shown that the candidate arrangements (a), (b), and (g) must have the same home bias $\alpha^{i}=\alpha$, for $i \in \mathcal{I}$, I now use a square root production function to get closed-form solutions. The two (symmetric) market clearing conditions are therefore

$$
1-k=\frac{\tau \Delta_{\epsilon} \sqrt{k}}{R}
$$

Plugging in (A1a),

$$
\begin{aligned}
R_{W W} & =\frac{1}{2 \mathbb{E}(\lambda)}\left(\mathbb{E}(\epsilon)(1-\tau)\left(\mathbb{E}(\epsilon)(1-\tau)+2 \mathbb{E}(\lambda) \tau \Delta_{\epsilon}\right)\right)^{1 / 2} \\
k_{W W} & =\frac{\mathbb{E}(\epsilon)(1-\tau)}{\mathbb{E}(\epsilon)(1-\tau)+2 \mathbb{E}(\lambda) \tau \Delta_{\epsilon}} \\
D_{W W} & =\frac{2 \mathbb{E}(\lambda) \tau \Delta_{\epsilon}}{\mathbb{E}(\epsilon)(1-\tau)+2 \mathbb{E}(\lambda) \tau \Delta_{\epsilon}}
\end{aligned}
$$

where the subscript $W W$ indicates that the capitalization level of the financial sector. Note that $k_{W W} \in(0,1)$. It is also easy to show that $\frac{\partial k_{W W}}{\partial \tau}<0, \frac{\partial k_{W W}}{\partial \gamma}>0$, and $\frac{\partial R_{W W}}{\partial \gamma}<0$.

Proof of Proposition 2. Note first that $\mathbb{E}(\lambda)<1$. First, I show that arrangements (a), (f), (e), and $(\mathrm{g})$ are not candidate equilibria when at least one banking sector risk-shifts. Arrangement (a): in the UU case, in equilibrium it must be that $R^{A}>R^{B}$ and $R^{B}>R^{A}$ to have both financial sector investing abroad. In the UW case, similarly, in equilibrium it must be that $R^{B}>R^{A}$ and $R^{B}=R^{A}$. Case WU is symmetric. In each of these three cases we reached a contradiction. Arrangement $(\mathrm{g})$ : in the UU case, in equilibrium it must be that $R^{A} \leq \mathbb{E}(\lambda) R^{B} \leq \mathbb{E}(\lambda)^{2} R^{A}$. In the UW case in equilibrium it must be that $R^{A} \leq \mathbb{E}(\lambda) R^{B} \leq \mathbb{E}(\lambda) R^{A}$. Case WU is symmetric. In each of these three cases we reached a contradiction. Arrangement (f): in the UU case, in equilibrium it must be that $R^{A}=\theta R^{B}$. In the UW case in equilibrium it must be that $R^{B} \leq \mathbb{E}(\lambda) R^{A} \leq \mathbb{E}(\lambda)^{2} R^{B}$. In the WU case in equilibrium it must be that $R^{A}=R^{B}$ and $R^{B}<\mathbb{E}(\lambda) R^{A}$. Arrangement (e) 

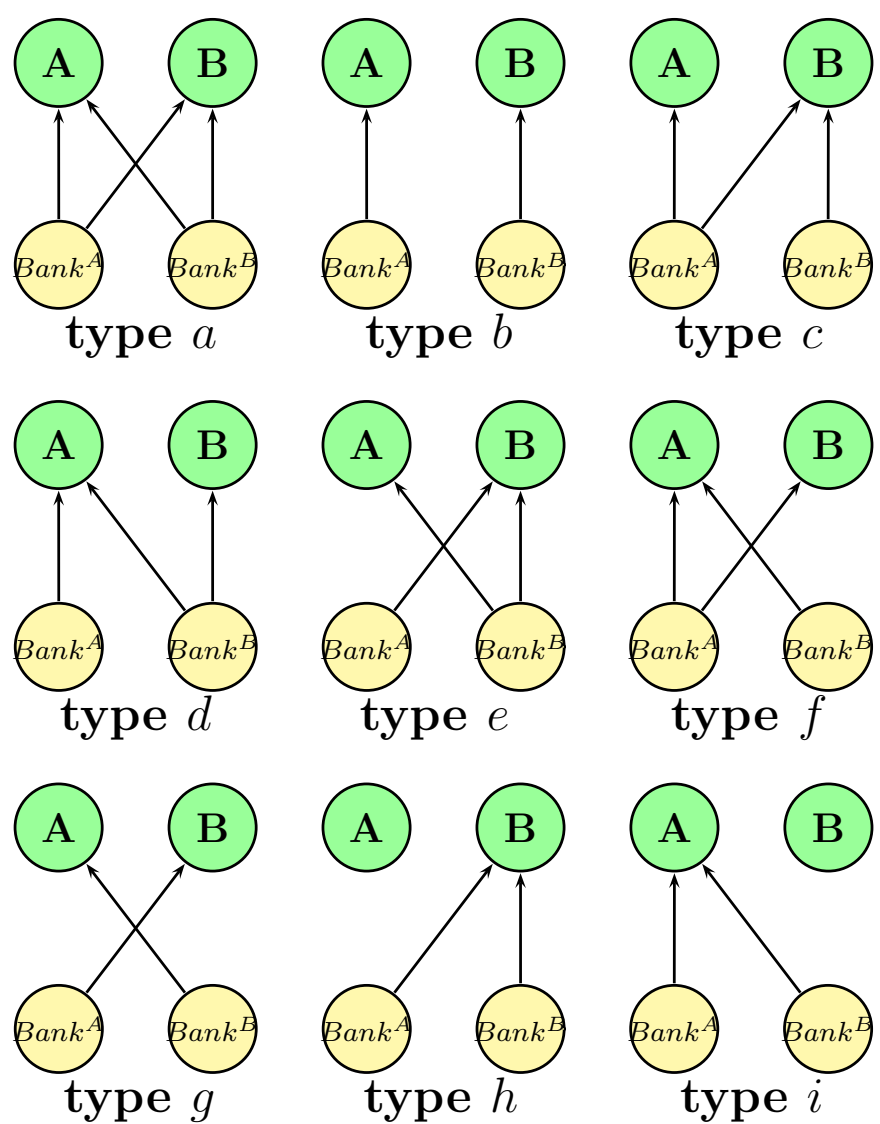

type $i$

Figure A.1: Nine Candidate Arrangements. This figure illustrates the nine possible types of arrangements between banks and governments in the economy. Note that the degenerate arrangements where a bank does not invest in the bond markets is not included.

follows by symmetry. The proof used in Proposition 1 can be used again to show that arrangements (h) and (i) are not candidate equilibria. Finally, arrangement (c) in UU and UW case is not an equilibria as markets do not clear $\left(R^{B}>R^{A}\right.$ and $\left.k^{B}<k^{A}\right)$. In the WU case, arrangement (c) is a viable equilibria only if $\gamma<1-\theta$. Finally, arrangement (b) is always an equilibrium as long as one financial sector is undercapitalized. Equilibrium prices solve, in each country,

$$
1-k^{i}=\frac{\tau \Delta_{\epsilon} f\left(k^{i}\right)}{R^{i}}
$$

Proof of Corollary 1. From (A2a)-(A2c) and (A3a)-(A3c) the claim trivially follows.

Closed-Form Solutions. I get closed-form solutions using a square root production function. From Proposition 2, when both financial sectors are undercapitalized, the economy has a unique 
"financial autarky" equilibrium where both financial sectors invest only domestically.

$$
\begin{aligned}
& R_{U U}^{i}=R_{U U}=\frac{1}{2}\left((1-\tau) \epsilon_{H}\left((1-\tau) \epsilon_{H}+2 \tau \Delta_{\epsilon}\right)\right)^{1 / 2} \\
& k_{U U}^{i}=k_{U U}=\frac{(1-\tau) \epsilon_{H}}{(1-\tau) \epsilon_{H}+2 \tau \Delta_{\epsilon}} \\
& D_{U U}^{i}=D_{U U}=\frac{2 \tau \Delta_{\epsilon}}{(1-\tau) \epsilon_{H}+2 \tau \Delta_{\epsilon}}
\end{aligned}
$$

Note that $k_{U U} \in(0,1)$ iff $\gamma<(1-\theta)+(1-\tau+2 \tau \theta) \epsilon_{H}\left(2 \tau \epsilon_{L}\right)^{-1}$. In the case where one financial sector is undercapitalized and one financial sector is well capitalized the unique equilibrium:

$$
\begin{aligned}
R_{U W}^{A} & =R_{U U} \\
R_{U W}^{B} & =R_{W W} \\
k_{U W}^{A} & =k_{U U} \\
k_{U W}^{B} & =k_{W W} \\
D_{U W}^{A} & =D_{U U} \\
D_{U W}^{B} & =D_{W W}
\end{aligned}
$$

Proof of Proposition 3. Define the banks' payoff in the good state and in the bad state, with perfect home bias, as follows:

$$
\begin{aligned}
\Pi^{\text {high }}(k) & =(1-\tau) \epsilon_{H} f(k)+R(1-k) \\
& =\left((1-\tau) \epsilon_{H}+\tau \Delta_{\epsilon}\right) f(k) \\
\Pi^{\text {low }}(k) & =(1-\tau) \epsilon_{L} f(k)+R \lambda(1-k) \\
& =(1-\tau \gamma) f(k)
\end{aligned}
$$

It is easy to show that $\Pi^{\text {low }}(\tilde{k})<\Pi^{h i g h}(\tilde{k})$, for every $\tilde{k}$. Define the unconstrained problem

$$
\max _{k} \mathbb{E}(\Pi(k))-L
$$

with solution $k^{*} \in(0,1)$ and the (limited liability) constrained problem

$$
\max _{k} \theta \Pi^{h i g h}(k)-L \theta
$$

with solution $k^{* *}$. Finally, let $\bar{k}$ be such that $\Pi^{\text {low }}(\bar{k})=L$. If the limited liability constraint does not bind, banks solve the unconstrained problem. If the limited liability constraint binds, banks solve the the constrained problem. There are four cases: (i) if $k^{*} \geq \bar{k}$ and $k^{* *} \geq \bar{k}$, the solution is 
$k^{*}$ as

$$
\begin{aligned}
\mathbb{E}\left(\Pi\left(k^{*}\right)\right)-L & =\theta \Pi^{\text {high }}\left(k^{*}\right)-L \theta+(1-\theta) \Pi^{\text {low }}\left(k^{*}\right)-L(1-\theta) \\
& \geq \theta \Pi^{\text {high }}\left(k^{* *}\right)-L \theta+(1-\theta) \Pi^{\text {low }}\left(k^{*}\right)-L(1-\theta) \\
& \geq \theta \Pi^{\text {high }}\left(k^{* *}\right)-L \theta
\end{aligned}
$$

(ii) if $k^{*} \leq \bar{k}$ and $k^{* *} \leq \bar{k}$, the solution is $k^{* *}$ as

$$
\begin{aligned}
\theta \Pi^{\text {high }}\left(k^{* *}\right)-L \theta & =\theta \Pi^{\text {high }}\left(k^{*}\right)-L \theta \\
& \geq \theta \Pi^{\text {high }}\left(k^{*}\right)-L \theta+(1-\theta) \Pi^{\text {low }}\left(k^{*}\right)-L(1-\theta) \\
& \geq \mathbb{E}\left(\Pi\left(k^{*}\right)\right)-L
\end{aligned}
$$

(iii) if $k^{*} \geq \bar{k}$ and $k^{* *} \leq \bar{k}$, the solution is $k^{*}$ as

$$
\begin{aligned}
\mathbb{E}\left(\Pi\left(k^{*}\right)\right)-L & \geq \theta \Pi^{\text {high }}\left(k^{*}\right)-L \theta+(1-\theta) \Pi^{\text {low }}\left(k^{*}\right)-L(1-\theta) \\
& \geq \theta \Pi^{\text {high }}\left(k^{* *}\right)-L \theta+(1-\theta) \Pi^{\text {low }}\left(k^{*}\right)-L(1-\theta) \\
& \geq \theta \Pi^{h i g h}\left(k^{* *}\right)-L \theta
\end{aligned}
$$

(iv) if $k^{*} \leq \bar{k}$ and $k^{* *} \geq \bar{k}$, the solution is $k^{* *}$ as

$$
\begin{aligned}
\theta \Pi^{\text {high }}\left(k^{* *}\right)- & L \theta+(1-\theta) \Pi^{\text {high }}\left(k^{* *}\right)-L(1-\theta) \\
& \geq \theta \Pi^{\text {high }}\left(k^{* *}\right)-L \theta+(1-\theta) \Pi^{\text {high }}\left(k^{*}\right)-L(1-\theta) \\
& \geq \theta \Pi^{\text {high }}\left(k^{* *}\right)-L \theta \\
& \geq \theta \Pi^{\text {high }}\left(k^{*}\right)-L \theta
\end{aligned}
$$

as $k^{* *} \geq k^{*}$. Hence, the solution to the banks' portfolio problem is $k^{*}$ if $k^{*} \geq \bar{k}$ and $k^{* *}$ if $k^{*}<\bar{k}$. We can then obtain the threshold debt level $\bar{L}$ such that $\bar{L}=(1-\tau \gamma)\left(k_{W W}\right)^{1 / 2}$. If $L \leq \bar{L}$, the banks are unconstrained and if $L>\bar{L}$ banks are constrained.

\section{A.2 Extensions}

This subsection provides derivations and proofs with reference to Section 4.2.

Relaxing Assumption 1: Foreign Private Lending Let $\mu \in(0,1)$ be the fraction of investment in the private lending technology that is allocated domestically. Since the two lending technologies are identical, banks are indifferent whether investing in domestic or foreign private lending and tax collection in state $s \in \mathcal{S}$ is $\tau f(k)\left(\epsilon_{s}(\mu)^{1 / 2}+\mathbb{E}(\epsilon)(1-\mu)^{1 / 2}\right)$.

Let $\lambda_{s^{i}, s^{j}}^{i}$ be the recovery value on government bonds of country $i$ when country $i$ is in state $s^{i} \in \mathcal{S}$ and country $j$ is $s^{j} \in \mathcal{S}(i \neq j)$. By construction, $\lambda_{s^{i}, s^{j}}^{i}$ is such that

$$
\begin{aligned}
D^{i} R^{i} \lambda_{s^{i}, s^{j}}^{i} & =\left(\epsilon_{s^{i}}\left(\mu^{i}\right)^{1 / 2}+\epsilon_{s^{j}}\left(1-\mu^{i}\right)^{1 / 2}\right) \tau f(k)-g \\
\lambda_{s^{i}, s^{j}}^{i} & =\frac{\epsilon_{s^{i}}\left(\mu^{i}\right)^{1 / 2}+\epsilon_{s^{j}}\left(1-\mu^{i}\right)^{1 / 2}-\gamma \epsilon_{L}}{\mathbb{E}(\epsilon)\left(\left(\mu_{i}\right)^{1 / 2}+(\epsilon)\left(1-\mu_{i}\right)^{1 / 2}\right)-\gamma \epsilon_{L}} \quad \forall s^{i}, s^{j} \in \mathcal{S}
\end{aligned}
$$


It is then trivial to show that (i) if $s^{i}=s^{j}=H$ there is never default, (ii) if $s^{i}=H$ and $s^{j}=L$ there is no default if and only if $\mu \geq \bar{\mu}$, (iii) if $s^{i}=L$ and $s^{j}=H$ there is no default if and only if $\mu \leq \overline{\bar{\mu}}$, (iv) if $s^{i}=s^{j}=L$ there is always default, where $\bar{\mu}$ is such that $(1-\theta)(\bar{\mu})^{1 / 2}=\theta(1-\bar{\mu})^{1 / 2}$ and $\overline{\bar{\mu}}$ is such that $\theta(\overline{\bar{\mu}})^{1 / 2}=(1-\theta)(1-\overline{\bar{\mu}})^{1 / 2}$.

We can then solve for the expected recovery value of domestic and foreign government bonds at $t=0$.

$$
\begin{aligned}
& \mathbb{E}\left(\lambda_{H, s^{j}}^{i}\right)=\theta+(1-\theta)\left(1-\mathbb{1}_{\mu^{i} \leq \bar{\mu}}\left(1-\lambda_{H, L}^{i}\right)\right) \\
& \mathbb{E}\left(\lambda_{L, s^{j}}^{i}\right)=\theta\left(1-\mathbb{1}_{\mu^{i}>\overline{\bar{\mu}}}\left(1-\lambda_{L, H}^{i}\right)\right)+(1-\theta) \lambda_{L, L}^{i} \\
& \mathbb{E}\left(\lambda_{H, s^{j}}^{j}\right)=\theta+(1-\theta)\left(1-\mathbb{1}_{\mu^{j}>\overline{\bar{\mu}}}\left(1-\lambda_{H, L}^{j}\right)\right) \\
& \mathbb{E}\left(\lambda_{L, s^{j}}^{j}\right)=\theta\left(1-\mathbb{1}_{\mu^{j} \geq \bar{\mu}}\left(1-\lambda_{L, H}^{j}\right)\right)+(1-\theta) \lambda_{L, L}^{i}
\end{aligned}
$$

One can show that $\mathbb{E}\left(\lambda_{H, s^{j}}^{i}\right)>\mathbb{E}\left(\lambda_{L, s^{j}}^{i}\right)$ and $\mathbb{E}\left(\lambda_{H, s^{j}}^{j}\right)>\mathbb{E}\left(\lambda_{L, s^{j}}^{j}\right)$, implying that the payoff in the domestic bad state of the world is still dominated by the payoff in the good state. When well capitalized banks invest domestically if

$$
R \geq R^{*}
$$

When undercapitalized banks invest domestcailly if and only if

$$
R \geq\left(\frac{\mathbb{E}\left(\lambda_{H, j}^{j}\right)}{\mathbb{E}\left(\lambda_{H, j}^{i}\right)}\right) R^{*}
$$

where $\frac{\mathbb{E}\left(\lambda_{H, j}^{j}\right)}{\mathbb{E}\left(\lambda_{H, j}^{i}\right)}<1$ if and only if $\mu^{i} \geq \bar{\mu}$ and $\mu^{j} \geq \overline{\bar{\mu}}$.

Relaxing Assumption 2: Correlated Shocks Assume that $\operatorname{corr}\left(\epsilon^{A}, \epsilon^{B}\right)=\rho$. Lemma 1 holds ( $\lambda$ is unchanged from the baseline model). Hence, the probabilities in the four states of the world are

$$
\begin{aligned}
& \operatorname{Prob}\left(s^{A}=H \cap s^{B}=H\right)=\theta(1-(1-\rho)(1-\theta)) \\
& \operatorname{Prob}\left(s^{A}=H \cap s^{B}=L\right)=\operatorname{Prob}\left(s^{A}=L \cap s^{B}=H\right)=(1-\rho) \theta(1-\theta) \\
& \operatorname{Prob}\left(s^{A}=L \cap s^{B}=L\right)=(1-\theta)(\rho+(1-\rho)(1-\theta))
\end{aligned}
$$

Consider country $A$ ( $B$ follows by symmetry). Domestic government bonds pay $R$ in the good state and $\lambda R$ in the bad state. Foreign government bonds pay $(1-(1-\rho)(1-\theta))+\lambda(1-\rho)(1-\theta)$ in the good state and $\theta(1-\rho)+\lambda(\rho+(1-\rho)(1-\theta))$ in the bad state where I used the following conditional probabilities

$$
\begin{aligned}
& \operatorname{Prob}\left(s^{B}=L \mid s^{A}=H\right)=(1-\rho)(1-\theta) \\
& \operatorname{Prob}\left(s^{B}=H \mid s^{A}=H\right)=1-(1-\rho)(1-\theta) \\
& \operatorname{Prob}\left(s^{B}=L \mid s^{A}=L\right)=\rho+(1-\rho)(1-\theta) \\
& \operatorname{Prob}\left(s^{B}=H \mid s^{A}=L\right)=\theta(1-\rho)
\end{aligned}
$$


In the $W$ case banks invest domestically if and only if $R \geq R^{*}$. In the $U$ case, banks invest domestically if and only if

$$
R \geq R^{*}(1-(1-\lambda)(1-\rho)(1-\theta))
$$

Relaxing Assumption 3: One Safe Country, One Risky Country Assume now that $\theta^{A}<1$ and $\theta^{B}=1$. Moreover, assume that $\Delta_{\epsilon}^{i}=\theta^{A}+\left(1-\theta^{A}-\gamma\right)$ for $i \in \mathcal{I}$. In other words, an investment of $y$ in country $A$ lending technology yields, in expectation, the same in country $B$ lending technology. The two government debt capacities are

$$
D^{i} R^{i}=\tau f\left(k^{i}\right) \Delta_{\epsilon}
$$

Lemma 1 holds for country $A$ as in the bad state it partially defaults (haircut $\lambda^{A}$ ). Country $B$ is riskless and never defaults: its banks are always well capitalized as there is no uncertainty. The banking sector optimal investment $k^{B}$ is given by

$$
k^{B}=\left(\frac{(1-\tau) \mathbb{E}^{A}(\epsilon)}{2\left(\alpha R^{B}+(1-\alpha) R^{A} \mathbb{E}^{A}\left(\lambda^{A}\right)\right)}\right)^{2}
$$

In the $W W$ case, countries invest in $A$ 's debt if and only if $R^{A} \mathbb{E}^{A}\left(\lambda^{A}\right) \geq R^{B}$. The only possible arrangement is therefore (a) where both countries face a strictly positive demand for their own debt. ${ }^{32}$ Hence, $R^{A} \mathbb{E}^{A}\left(\lambda^{A}\right)=R^{B}$ and $k^{A}=k^{B}=k$. From the two market clearing conditions, in equilibrium, it must be that $\alpha^{A}<\alpha^{B}, D^{B}>D^{A}$, and $R^{B}<R^{A}$.

In the $U W$ case banks in $A$ invest domestically if and only if $R^{A} \geq R^{B}$ and banks in $B$ invest domestically if and only if $R^{B} \geq \mathbb{E}^{A}\left(\lambda^{A}\right) R^{A}$. We can discard arrangements (h) and (i) because they would, as proved before, give a contradiction. Similarly arrangements (a), (e), (f), and (g) are not candidate equilibria as there are no prices such that banks optimize in equilibrium. In arrangement (c), $R^{A}=R^{B}$ and $k^{A}>k^{B}$, and markets do not clear. Arrangement (d), if $1-\theta>\gamma$ is an equilibrium with $k^{A} \geq k^{B}$ and $R^{A} \geq R^{B}$. Finally, the financial autarky equilibrium (b) is characterized as usual.

Relaxing Assumption 4: Lending Technology with General Functional Form No results in the paper rely on the square-root functional form, which is assumed without loss of generality.

Relaxing Assumption 5: $\gamma<1-\boldsymbol{\theta}$ Suppose the economy is in the $U W$ state. The only candidate arrangements are type b and c. Type b is an autarkic equilibrium with the following

\footnotetext{
${ }^{32}$ The arrangements where one country faces zero demand for its debt ((h) and (i)) are not candidate equilibria as the interest rate on such country debt would go to infinite in equilibrium, attracting domestic and foreign investors.
} 
quantities and prices.

$$
\begin{aligned}
R_{U W, a u t}^{A} & =R_{U U} \\
R_{U W, a u t}^{B} & =R_{W W} \\
k_{U W, a u t}^{A} & =k_{U U} \\
k_{U W, a u t}^{B} & =k_{W W} \\
D_{U W, a u t}^{A} & =D_{U U} \\
D_{U W, a u t}^{B} & =D_{W W}
\end{aligned}
$$

where aut indicates "autarky". In the asymmetric equilibrium or type c arrangement, we have

$$
\begin{aligned}
R_{U W, a s y}^{i} & =R_{U W, a s y}=\left(\left(R_{W W}\right)^{2}+\left(R_{U U}\right)^{2}\right)^{1 / 2} \\
k_{U W, a s y}^{A} & =\left(\frac{(1-\tau) \epsilon_{H}}{2 R_{U W, a s y}}\right)^{2} \\
k_{U W, a u t}^{B} & =\left(\frac{(1-\tau) \mathbb{E}(\epsilon)}{2 \mathbb{E}(\lambda) R_{U W, a s y}}\right)^{2} \\
\alpha_{U W, a s y}^{B} & =\frac{2 \tau \Delta_{\epsilon}(1-\tau) \mathbb{E}(\epsilon)}{\mathbb{E}(\lambda) \epsilon_{H}(1-\tau)\left(\epsilon_{H}(1-\tau)+2 \tau \Delta_{\epsilon}\right)+2 \tau \Delta_{\epsilon}(1-\tau) \mathbb{E}(\epsilon)} \\
D_{U W, a s y}^{A} & =\left(1-k_{U W, a s y}^{A}\right)+\left(1-\alpha_{U W, a s y}^{B}\right)\left(1-k_{U W, a u t}^{B}\right) \\
D_{U W, a s y}^{B} & =\alpha_{U W, a s y}^{B}\left(1-k_{U W, a u t}^{B}\right)
\end{aligned}
$$

where asy indicates that the equilibrium is asymmetric (the well capitalized financial sector invests domestically and non-domestically). 


\section{B Data Appendix}

This section describes, in detail, the construction of the dataset used in the analysis of Section 5 . Data and code are publicly available at http://people.stern.nyu.edu/mcrosign/.

Data Sources I use two data sources: European Banking Authority (EBA) stress test data and Bankscope. EBA data provides the country-level sovereign debt exposure of each bank at each stress test date. For example, one can see what is the exposure of Santander to the Italian sovereign in June 2013. Bankscope is used to get EBA sample banks' balance sheet variables. The reported exposures are the on-balance sheet exposures (accounting information) which are identified on an immediate borrower basis (e.g., an exposure of 100 towards Country A, collateralized with bonds issued by Country B, is reported on Country A but not on Country B)". Moreover, central bank deposits are not included so that the definition does not include exposures to counterparts (other than sovereigns) with full or partial guarantees from central, local or regional governments." Source: Capital Buffers for Addressing Market Concerns Over Sovereign Exposures, 2011 EBA EU-Wide Stress Test Methodological Note.

EBA data is publicly available at http://www.eba.europa.eu. As mentioned in the main body of the paper, the EBA conducted eight stress tests between October 2009 and June 2013 in order to "ensure the orderly functioning and integrity of financial markets and the stability of the financial system in the EU". The name of the stress tests changed through time: there were three "EU-wide Stress Tests" (October 2009, March 2010, December 2010), three "Capital Exercises" (September 2011, December 2011, June 2012), and two "Transparency Exercises" (December 2012, June 2013). As the EBA did not disclose data on sovereign exposure on the October 2009 test, I use the last seven stress tests for our analysis. The number of banks that participated in the remaining seven stress tests are, respectively (i) 91, (ii) 90, (iii) 65, (iv) 61, (v) 61, (vi) 64, (vii) 64. Each dataset was released in July 2010 (second stress test), July 2011 (third stress test), December 2011 (first Capital Exercise), October 2012 (second and third Capital Exercises), and December 2013 (Transparency Exercises). I use SNL Financial to get data on the second stress test and EBA website for the last six stress tests. The EBA dataset is a panel $(i, j, t)$, where $i \in \mathcal{N}$ is a financial institution, $j \in \mathcal{J}$ is a country, and $t \in \mathcal{T}$ is a stress test date. Each observation is a "gross direct long exposure" of bank $i$ to country $j$ at time $t$. According to the authority, "Sovereign debt exposures for the purpose of the capital exercise are those towards the central, regional and local governments of the European Economic Area (EEA) countries. (...) Central bank deposits are not included. Furthermore, the definition does not include exposures to counterparts (other than sovereigns) with full or partial guarantees from central, local or regional governments." 33 Gross exposures include direct and indirect sovereign exposures (i.e., on- and off-balance sheet) in the trading and in the banking book. During the exercise, banks have been asked to assess the valuation of their sovereign exposures according to market prices. The EBA has conducted this assessment using publicly available data including bonds yields, sovereign by sovereign and maturity by maturity, for a basket of government bonds. Some stress tests also disclosed the Exposure at

\footnotetext{
${ }^{33} \mathrm{EBA}$ states that "the exposures to be reported arise from immediate borrower basis (e.g. an exposure of 100 towards Country A, collateralised with bonds issued by Country B, is reported on Country A but not on Country B) and do not include exposures to other counterparts with full or partial government guarantees.
} 
Default (EAD) of bank $i$ to country $j$ at time $t$. The EAD measures the total credit risk exposure, including private credit. I use the December 2010 stress test EAD to classify banks according to their international diversification.

I use Bankscope to get data on Total Assets, Tier 1 Ratio, Risk Weighted Assets (RWA), Leverage, and Deposits.

Sample Construction Table B.2 shows the sample of banks that were stressed by the EBA. For each bank, the third column shows the country of incorporation and the fourth column shows the number of observations. Columns (5)-(11) illustrate whether the bank-time observation was available in a specific stress test date $t \in \mathcal{T}$ for a specific bank $i \in \mathcal{N}$. I discard banks with three or less stress test observations and the four Greek banks that have been subject to only the first two and the last two stress tests, shrinking the sample to 61 banks in 20 countries (selected banks are labeled with a check-mark in the last column and the last line sums all selected observations for each stress test date). For bank-period pair $(i, t)$, EBA provides data on exposures to selected countries $j \in \mathcal{J}{ }^{34}$ I further partition countries (both countries of banks' incorporation and countries $j \in \mathcal{J}$ ) in three different categories: (i) Core (Austria, Belgium, France, Germany, and Netherlands) and (ii) GIIPS (Italy, Ireland, Portugal, and Spain). I am able to match all banks to Bankscope, even though few have them have some missing datapoints. ${ }^{35}$ The match with Bankscope is done manually, using bank names. I match stress-test dates with Bankscope end-of-the year dates as follows: 31-Mar-10 matched to 2009 Bankscope; 31-Dec-10 matched to 2010 Bankscope; 30-Sep11, 31-Dec-11, 30-Jun-12 matched to 2011 Bankscope; 31-Dec-12 and 30-Jun-13 matched to 2012 Bankscope.

Hence, the final dataset is made of triples $(i, j, t)$, where $i \in \mathcal{N}$ (sample of 61 Bankscope-EBA matched banks), $j \in \mathcal{J}$ (the sample of 30 selected countries which the EBA reports the bank-level exposure to), and $t \in \mathcal{T}$ (sample of 7 EBA stress-tests dates). Moreover, for each $(i, t)$ pair, there is a corresponding total asset, tier 1 ratio, risk weighted assets (RWA), leverage, and deposits from Bankscope, and bank country of incorporation from EBA.

\footnotetext{
${ }^{34}$ I select the following countries $j \in \mathcal{J}$ : Belgium, Bulgaria, Cyprus, Czech Republic, Germany, Denmark, France, Estonia, Spain, Finland, United Kingdom, Greece, Hungary, Ireland, Iceland, Italy, Liechtenstein, Lithuania, Luxembourg, Latvia, Malta, Netherlands, Norway, Poland, Portugal, Romania, Sweden, Slovenia, Slovakia.

${ }^{35}$ Banks with four or more missing observations are Cyprus Popular Bank (missing 2012 and 2013 data), WGZ-Bank (missing Tier 1 Ratio and RWA in 2006-07, BPCE (missing 2006-07 data and majority of Tier 1 Ratio and RWA observations), Credit Agricole (missing RWA from 2006-07, Banque et Caisse d'Epargne de l'Etat Luxembourg (missing 2006 data and majority of Tier 1 Ratio and RWA observations), SNS Reaal (missing majority of Tier 1 Ratio and RWA observations), and ABN AMRO (missing 2006-08 data and majority of Tier 1 Ratio and RWA observations).
} 


\begin{tabular}{|c|c|c|c|c|c|c|c|c|c|c|c|}
\hline \multirow[t]{2}{*}{$\begin{array}{l}\text { EBA } \\
\text { ID }\end{array}$} & \multirow[t]{2}{*}{ Bank Name } & \multirow[t]{2}{*}{ Country } & \multirow[t]{2}{*}{$\mathbf{N}$} & \multirow{2}{*}{$\begin{array}{l}\text { Stress } \\
\text { Mar10 }\end{array}$} & \multirow{2}{*}{$\frac{\text { Tests }}{\text { Dec10 }}$} & \multicolumn{3}{|c|}{ Capital Exerc. } & \multicolumn{2}{|c|}{ Transp. Exerc. } & \\
\hline & & & & & & Sep11 & Dec11 & Jun12 & Dec12 & Jun13 & \\
\hline AT001 & Erste Group Bank & AT & 7 & $\mathrm{x}$ & $\mathrm{x}$ & $\mathrm{x}$ & $\mathrm{x}$ & $\mathrm{x}$ & $\mathrm{x}$ & $\mathrm{x}$ & $\checkmark$ \\
\hline AT002 & $\begin{array}{l}\text { Raiffeisen Zentralbank } \\
\text { Osterreich }\end{array}$ & $\mathrm{AT}$ & 7 & $\mathrm{x}$ & $\mathrm{x}$ & $\mathrm{x}$ & $\mathrm{x}$ & $\mathrm{x}$ & $\mathrm{x}$ & $\mathrm{x}$ & $\checkmark$ \\
\hline AT003 & $\begin{array}{l}\text { Oesterreichische } \\
\text { Volksbanken }\end{array}$ & $\mathrm{AT}$ & 2 & & $\mathrm{x}$ & $\mathrm{x}$ & & & & & \\
\hline BE004 & Dexia & $\mathrm{BE}$ & 3 & $\mathrm{x}$ & $\mathrm{x}$ & $\mathrm{x}$ & & & & & \\
\hline BE005 & KBC Bank & $\mathrm{BE}$ & 7 & $\mathrm{x}$ & $\mathrm{x}$ & $\mathrm{x}$ & $\mathrm{x}$ & $\mathrm{x}$ & $\mathrm{x}$ & $\mathrm{x}$ & $\checkmark$ \\
\hline CY006 & Cyprus Popular Bank & CY & 5 & $\mathrm{x}$ & $\mathrm{x}$ & $\mathrm{x}$ & $\mathrm{x}$ & $\mathrm{x}$ & & & $\checkmark$ \\
\hline CY007 & Bank of Cyprus & CY & 7 & $\mathrm{x}$ & $\mathrm{x}$ & $\mathrm{x}$ & $\mathrm{x}$ & $\mathrm{x}$ & $\mathrm{x}$ & $\mathrm{x}$ & $\checkmark$ \\
\hline DK008 & Danske Bank & DK & 7 & $\mathrm{x}$ & $\mathrm{x}$ & $\mathrm{x}$ & $\mathrm{x}$ & $\mathrm{x}$ & $\mathrm{x}$ & $\mathrm{x}$ & $\checkmark$ \\
\hline DK009 & Jyske Bank & DK & 7 & $\mathrm{x}$ & $\mathrm{x}$ & $\mathrm{x}$ & $\mathrm{x}$ & $\mathrm{x}$ & $\mathrm{x}$ & $\mathrm{x}$ & $\checkmark$ \\
\hline DK010 & Sydbank & DK & 7 & $\mathrm{x}$ & $\mathrm{x}$ & $\mathrm{x}$ & $\mathrm{x}$ & $\mathrm{x}$ & $\mathrm{x}$ & $\mathrm{x}$ & $\checkmark$ \\
\hline DK011 & Nykredit & DK & 6 & & $\mathrm{x}$ & $\mathrm{x}$ & $\mathrm{x}$ & $\mathrm{x}$ & $\mathrm{x}$ & $\mathrm{x}$ & $\checkmark$ \\
\hline FR013 & BNP Paribas & $\mathrm{FR}$ & 7 & $\mathrm{x}$ & $\mathrm{x}$ & $\mathrm{x}$ & $\mathrm{x}$ & $\mathrm{x}$ & $\mathrm{x}$ & $\mathrm{x}$ & $\checkmark$ \\
\hline FR014 & Credit Agricole & $\mathrm{FR}$ & 7 & $\mathrm{x}$ & $\mathrm{x}$ & $\mathrm{x}$ & $\mathrm{x}$ & $\mathrm{x}$ & $\mathrm{x}$ & $\mathrm{x}$ & $\checkmark$ \\
\hline FR015 & BPCE & FR & 7 & $\mathrm{x}$ & $\mathrm{x}$ & $\mathrm{x}$ & $\mathrm{x}$ & $\mathrm{x}$ & $\mathrm{x}$ & $\mathrm{x}$ & $\checkmark$ \\
\hline FR016 & Societe General & $\mathrm{FR}$ & 7 & $\mathrm{x}$ & $\mathrm{x}$ & $\mathrm{x}$ & $\mathrm{x}$ & $\mathrm{x}$ & $\mathrm{x}$ & $\mathrm{x}$ & $\checkmark$ \\
\hline DE017 & Deutsche Bank & $\mathrm{DE}$ & 7 & $\mathrm{x}$ & $\mathrm{x}$ & $\mathrm{x}$ & $\mathrm{x}$ & $\mathrm{x}$ & $\mathrm{x}$ & $\mathrm{x}$ & $\checkmark$ \\
\hline DE018 & Commerzbank & $\mathrm{DE}$ & 7 & $\mathrm{x}$ & $\mathrm{x}$ & $\mathrm{x}$ & $\mathrm{x}$ & $\mathrm{x}$ & $\mathrm{x}$ & $\mathrm{x}$ & $\checkmark$ \\
\hline DE019 & $\begin{array}{l}\text { Landesbank } \\
\text { Baden-Wurttemberg }\end{array}$ & $\mathrm{DE}$ & 7 & $\mathrm{x}$ & $\mathrm{x}$ & $\mathrm{x}$ & $\mathrm{x}$ & $\mathrm{x}$ & $\mathrm{x}$ & $\mathrm{x}$ & $\checkmark$ \\
\hline DE020 & DZ Bank & $\mathrm{DE}$ & 7 & $\mathrm{x}$ & $\mathrm{x}$ & $\mathrm{x}$ & $\mathrm{x}$ & $\mathrm{x}$ & $\mathrm{x}$ & $\mathrm{x}$ & $\checkmark$ \\
\hline DE021 & Bayerische Landesbank & $\mathrm{DE}$ & 7 & $\mathrm{x}$ & $\mathrm{x}$ & $\mathrm{x}$ & $\mathrm{x}$ & $\mathrm{x}$ & $\mathrm{x}$ & $\mathrm{x}$ & $\checkmark$ \\
\hline $\mathrm{DE} 022$ & $\begin{array}{l}\text { Norddeutsche } \\
\text { Landesbank }\end{array}$ & $\mathrm{DE}$ & 7 & $\mathrm{x}$ & $\mathrm{x}$ & $\mathrm{x}$ & $\mathrm{x}$ & $\mathrm{x}$ & $\mathrm{x}$ & $\mathrm{x}$ & $\checkmark$ \\
\hline DE023 & HRE Holding & $\mathrm{DE}$ & 7 & $\mathrm{x}$ & $\mathrm{x}$ & $\mathrm{x}$ & $\mathrm{x}$ & $\mathrm{x}$ & $\mathrm{x}$ & $\mathrm{x}$ & $\checkmark$ \\
\hline DE024 & WestLB & $\mathrm{DE}$ & 3 & $\mathrm{x}$ & $\mathrm{x}$ & $\mathrm{x}$ & & & & & \\
\hline DE025 & HSH Nordbank & $\mathrm{DE}$ & 7 & $\mathrm{x}$ & $\mathrm{x}$ & $\mathrm{x}$ & $\mathrm{x}$ & $\mathrm{x}$ & $\mathrm{x}$ & $\mathrm{x}$ & $\checkmark$ \\
\hline na & Deutsche Postbank & $\mathrm{DE}$ & 1 & $\mathrm{x}$ & & & & & & & \\
\hline DE028 & DekaBank & $\mathrm{DE}$ & 7 & $\mathrm{x}$ & $\mathrm{x}$ & $\mathrm{x}$ & $\mathrm{x}$ & $\mathrm{x}$ & $\mathrm{x}$ & $\mathrm{x}$ & $\checkmark$ \\
\hline DE029 & WGZ Bank & $\mathrm{DE}$ & 7 & $\mathrm{x}$ & $\mathrm{x}$ & $\mathrm{x}$ & $\mathrm{x}$ & $\mathrm{x}$ & $\mathrm{x}$ & $\mathrm{x}$ & $\checkmark$ \\
\hline GR030 & EFG Eurobank Ergasias & GR & 4 & $\mathrm{x}$ & $\mathrm{x}$ & & & & $\mathrm{x}$ & $\mathrm{x}$ & \\
\hline GR031 & National Bank of Greece & GR & 4 & $\mathrm{x}$ & $\mathrm{x}$ & & & & $\mathrm{x}$ & $\mathrm{x}$ & \\
\hline GR032 & Alpha Bank & GR & 4 & $\mathrm{x}$ & $\mathrm{x}$ & & & & $\mathrm{x}$ & $\mathrm{x}$ & \\
\hline GR033 & Piraeus Bank & GR & 4 & $\mathrm{x}$ & $\mathrm{x}$ & & & & $\mathrm{x}$ & $\mathrm{x}$ & \\
\hline GR034 & ATEbank & GR & 2 & $\mathrm{x}$ & $\mathrm{x}$ & & & & & & \\
\hline GR035 & TT Hellenic Postbank & GR & 2 & $\mathrm{x}$ & $\mathrm{x}$ & & & & & & \\
\hline HU036 & OTP Bank & $\mathrm{HU}$ & 7 & $\mathrm{x}$ & $\mathrm{x}$ & $\mathrm{x}$ & $\mathrm{x}$ & $\mathrm{x}$ & $\mathrm{x}$ & $\mathrm{x}$ & $\checkmark$ \\
\hline na & FHB Jelzalogbank & $\mathrm{HU}$ & 1 & $\mathrm{x}$ & & & & & & & \\
\hline IE037 & Allied Irish Banks & IE & 7 & $\mathrm{x}$ & $\mathrm{x}$ & $\mathrm{x}$ & $\mathrm{x}$ & $\mathrm{x}$ & $\mathrm{x}$ & $\mathrm{x}$ & $\checkmark$ \\
\hline IE038 & Bank of Ireland & $\mathrm{IE}$ & 7 & $\mathrm{x}$ & $\mathrm{x}$ & $\mathrm{x}$ & $\mathrm{x}$ & $\mathrm{x}$ & $\mathrm{x}$ & $\mathrm{x}$ & $\checkmark$ \\
\hline IE039 & Irish Life and Permanent & IE & 6 & & $\mathrm{x}$ & $\mathrm{x}$ & $\mathrm{x}$ & $\mathrm{x}$ & $\mathrm{x}$ & $\mathrm{x}$ & $\checkmark$ \\
\hline IT040 & Intesa Sanpaolo & IT & 7 & $\mathrm{x}$ & $\mathrm{x}$ & $\mathrm{x}$ & $\mathrm{x}$ & $\mathrm{x}$ & $\mathrm{x}$ & $\mathrm{x}$ & $\checkmark$ \\
\hline IT041 & Unicredit & IT & 7 & $\mathrm{x}$ & $\mathrm{x}$ & $\mathrm{x}$ & $\mathrm{x}$ & $\mathrm{x}$ & $\mathrm{x}$ & $\mathrm{x}$ & $\checkmark$ \\
\hline IT042 & $\begin{array}{l}\text { Banca Monte Paschi } \\
\text { Siena }\end{array}$ & IT & 7 & $\mathrm{x}$ & $\mathrm{x}$ & $\mathrm{x}$ & $\mathrm{x}$ & $\mathrm{x}$ & $\mathrm{x}$ & $\mathrm{x}$ & $\checkmark$ \\
\hline IT043 & Banco Popolare & IT & 7 & $\mathrm{x}$ & $\mathrm{x}$ & $\mathrm{x}$ & $\mathrm{x}$ & $\mathrm{x}$ & $\mathrm{x}$ & $\mathrm{x}$ & $\checkmark$ \\
\hline IT044 & UBI Banca & IT & 7 & $\mathrm{x}$ & $\mathrm{x}$ & $\mathrm{x}$ & $\mathrm{x}$ & $\mathrm{x}$ & $\mathrm{x}$ & $\mathrm{x}$ & $\checkmark$ \\
\hline LU045 & $\begin{array}{l}\text { Banque et Caisse } \\
\text { d'Epargne }\end{array}$ & $\mathrm{LU}$ & 7 & $\mathrm{x}$ & $\mathrm{x}$ & $\mathrm{x}$ & $\mathrm{x}$ & $\mathrm{x}$ & $\mathrm{x}$ & $\mathrm{x}$ & $\checkmark$ \\
\hline na & Banque Raiffeisen & $\mathrm{LU}$ & 1 & $\mathrm{x}$ & & & & & & & \\
\hline МТ046 & Bank of Valletta & MT & 7 & $\mathrm{x}$ & $\mathrm{x}$ & $\mathrm{x}$ & $\mathrm{x}$ & $\mathrm{x}$ & $\mathrm{x}$ & $\mathrm{x}$ & $\checkmark$ \\
\hline NL047 & ING Bank & NL & 7 & $\mathrm{x}$ & $\mathrm{x}$ & $\mathrm{x}$ & $\mathrm{x}$ & $\mathrm{x}$ & $\mathrm{x}$ & $\mathrm{x}$ & $\checkmark$ \\
\hline NL048 & Rabobank & NL & 7 & $\mathrm{x}$ & $\mathrm{x}$ & $\mathrm{x}$ & $\mathrm{x}$ & $\mathrm{x}$ & $\mathrm{x}$ & $\mathrm{x}$ & $\checkmark$ \\
\hline NL049 & ABN AMRO & $\mathrm{NL}$ & 7 & $\mathrm{x}$ & $\mathrm{x}$ & $\mathrm{x}$ & $\mathrm{x}$ & $\mathrm{x}$ & $\mathrm{x}$ & $\mathrm{x}$ & $\checkmark$ \\
\hline NL050 & SNS Bank & NL & 7 & $\mathrm{x}$ & $\mathrm{x}$ & $\mathrm{x}$ & $\mathrm{x}$ & $\mathrm{x}$ & $\mathrm{x}$ & $\mathrm{x}$ & $\checkmark$ \\
\hline NO051 & DNB & $\mathrm{NO}$ & 6 & & $\mathrm{x}$ & $\mathrm{x}$ & $\mathrm{x}$ & $\mathrm{x}$ & $\mathrm{x}$ & $\mathrm{x}$ & $\checkmark$ \\
\hline PL052 & PKO Bank Polski & PL & 7 & $\mathrm{x}$ & $\mathrm{x}$ & $\mathrm{x}$ & $\mathrm{x}$ & $\mathrm{x}$ & $\mathrm{x}$ & $\mathrm{x}$ & $\checkmark$ \\
\hline
\end{tabular}




\begin{tabular}{|c|c|c|c|c|c|c|c|c|c|c|c|}
\hline РT053 & Caixa Geral de Depositos & $\mathrm{PT}$ & 7 & $\mathrm{x}$ & $\mathrm{x}$ & $\mathrm{x}$ & $\mathrm{x}$ & $\mathrm{x}$ & $\mathrm{x}$ & $\mathrm{x}$ & $\checkmark$ \\
\hline PT054 & $\mathrm{BCP}$ & $\mathrm{PT}$ & 7 & $\mathrm{x}$ & $\mathrm{x}$ & $\mathrm{x}$ & $\mathrm{x}$ & $\mathrm{x}$ & $\mathrm{x}$ & $\mathrm{x}$ & $\checkmark$ \\
\hline РT055 & ESFG & $\mathrm{PT}$ & 7 & $\mathrm{x}$ & $\mathrm{x}$ & $\mathrm{x}$ & $\mathrm{x}$ & $\mathrm{x}$ & $\mathrm{x}$ & $\mathrm{x}$ & $\checkmark$ \\
\hline РT056 & Banco BPI & $\mathrm{PT}$ & 7 & $\mathrm{x}$ & $\mathrm{x}$ & $\mathrm{x}$ & $\mathrm{x}$ & $\mathrm{x}$ & $\mathrm{x}$ & $\mathrm{x}$ & $\checkmark$ \\
\hline SI057 & NLB & SI & 7 & $\mathrm{x}$ & $\mathrm{x}$ & $\mathrm{x}$ & $\mathrm{x}$ & $\mathrm{x}$ & $\mathrm{x}$ & $\mathrm{x}$ & $\checkmark$ \\
\hline SI058 & Nova KBM & SI & 6 & & $\mathrm{x}$ & $\mathrm{x}$ & $\mathrm{x}$ & $\mathrm{x}$ & $\mathrm{x}$ & $\mathrm{x}$ & $\checkmark$ \\
\hline ES059 & Banco Santander & ES & 7 & $\mathrm{x}$ & $\mathrm{x}$ & $\mathrm{x}$ & $\mathrm{x}$ & $\mathrm{x}$ & $\mathrm{x}$ & $\mathrm{x}$ & $\checkmark$ \\
\hline ES060 & BBVA & ES & 7 & $\mathrm{x}$ & $\mathrm{x}$ & $\mathrm{x}$ & $\mathrm{x}$ & $\mathrm{x}$ & $\mathrm{x}$ & $\mathrm{x}$ & $\checkmark$ \\
\hline ES061 & Jupiter & ES & 3 & $\mathrm{x}$ & $\mathrm{x}$ & $\mathrm{x}$ & & & & & \\
\hline ES062 & Caixa & $\mathrm{ES}$ & 7 & $\mathrm{x}$ & $\mathrm{x}$ & $\mathrm{x}$ & $\mathrm{x}$ & $\mathrm{x}$ & $\mathrm{x}$ & $\mathrm{x}$ & $\checkmark$ \\
\hline ES063 & Base & ES & 2 & $\mathrm{x}$ & $\mathrm{x}$ & & & & & & \\
\hline ES064 & Banco Popular Espanol & $\mathrm{ES}$ & 7 & $\mathrm{x}$ & $\mathrm{x}$ & $\mathrm{x}$ & $\mathrm{x}$ & $\mathrm{x}$ & $\mathrm{x}$ & $\mathrm{x}$ & $\checkmark$ \\
\hline ES065 & Banco de Sabadell & $\mathrm{ES}$ & 2 & $\mathrm{x}$ & $\mathrm{x}$ & & & & & & \\
\hline ES066 & Diada & ES & 2 & $\mathrm{x}$ & $\mathrm{x}$ & & & & & & \\
\hline ES067 & Breogan & ES & 2 & $\mathrm{x}$ & $\mathrm{x}$ & & & & & & \\
\hline ES068 & Mare Nostrum & ES & 2 & $\mathrm{x}$ & $\mathrm{x}$ & & & & & & \\
\hline ES069 & Bankinter & ES & 2 & $\mathrm{x}$ & $\mathrm{x}$ & & & & & & \\
\hline ES070 & Espiga & $\mathrm{ES}$ & 2 & $\mathrm{x}$ & $\mathrm{x}$ & & & & & & \\
\hline ES071 & Banca Civica & ES & 2 & $\mathrm{x}$ & $\mathrm{x}$ & & & & & & \\
\hline ES072 & Ibercaja & ES & 2 & $\mathrm{x}$ & $\mathrm{x}$ & & & & & & \\
\hline ES073 & Unicaja & ES & 2 & $\mathrm{x}$ & $\mathrm{x}$ & & & & & & \\
\hline ES074 & Banco Pastor & ES & 2 & $\mathrm{x}$ & $\mathrm{x}$ & & & & & & \\
\hline ES075 & Bilbao Bizkaia Kutxa & ES & 2 & $\mathrm{x}$ & $\mathrm{x}$ & & & & & & \\
\hline ES076 & Unnim & $\mathrm{ES}$ & 2 & $\mathrm{x}$ & $\mathrm{x}$ & & & & & & \\
\hline ES077 & Kutxa & $\mathrm{ES}$ & 2 & $\mathrm{x}$ & $\mathrm{x}$ & & & & & & \\
\hline ES078 & Banco Grupo Cajatres & $\mathrm{ES}$ & 2 & $\mathrm{x}$ & $\mathrm{x}$ & & & & & & \\
\hline ES079 & Banca March & $\mathrm{ES}$ & 2 & $\mathrm{x}$ & $\mathrm{x}$ & & & & & & \\
\hline ES080 & Caja Vital Kutxa & $\mathrm{ES}$ & 2 & $\mathrm{x}$ & $\mathrm{x}$ & & & & & & \\
\hline ES081 & Caixa Ontinyent & ES & 2 & $\mathrm{x}$ & $\mathrm{x}$ & & & & & & \\
\hline ES082 & Colonya, Caixa de Pollena & ES & 2 & $\mathrm{x}$ & $\mathrm{x}$ & & & & & & \\
\hline na & Cajasur & ES & 1 & $\mathrm{x}$ & & & & & & & \\
\hline na & Caja Sol & ES & 1 & $\mathrm{x}$ & & & & & & & \\
\hline na & Banco Guipuzcoano & ES & 1 & $\mathrm{x}$ & & & & & & & \\
\hline ES083 & Bankia & ES & 1 & & $\mathrm{x}$ & & & & & & \\
\hline SE084 & Nordea & SE & 7 & $\mathrm{x}$ & $\mathrm{x}$ & $\mathrm{x}$ & $\mathrm{x}$ & $\mathrm{x}$ & $\mathrm{x}$ & $\mathrm{x}$ & $\checkmark$ \\
\hline SE085 & SEB & SE & 7 & $\mathrm{x}$ & $\mathrm{x}$ & $\mathrm{x}$ & $\mathrm{x}$ & $\mathrm{x}$ & $\mathrm{x}$ & $\mathrm{x}$ & $\checkmark$ \\
\hline SE086 & Svenska Handelsbanken & $\mathrm{SE}$ & 7 & $\mathrm{x}$ & $\mathrm{x}$ & $\mathrm{x}$ & $\mathrm{x}$ & $\mathrm{x}$ & $\mathrm{x}$ & $\mathrm{x}$ & $\checkmark$ \\
\hline SE087 & Swedbank & $\mathrm{SE}$ & 7 & $\mathrm{x}$ & $\mathrm{x}$ & $\mathrm{x}$ & $\mathrm{x}$ & $\mathrm{x}$ & $\mathrm{x}$ & $\mathrm{x}$ & $\checkmark$ \\
\hline GB088 & RBS & GB & 7 & $\mathrm{x}$ & $\mathrm{x}$ & $\mathrm{x}$ & $\mathrm{x}$ & $\mathrm{x}$ & $\mathrm{x}$ & $\mathrm{x}$ & $\checkmark$ \\
\hline GB089 & HSBC & GB & 6 & & $\mathrm{x}$ & $\mathrm{x}$ & $\mathrm{x}$ & $\mathrm{x}$ & $\mathrm{x}$ & $\mathrm{x}$ & $\checkmark$ \\
\hline GB090 & Barclays & GB & 7 & $\mathrm{x}$ & $\mathrm{x}$ & $\mathrm{x}$ & $\mathrm{x}$ & $\mathrm{x}$ & $\mathrm{x}$ & $\mathrm{x}$ & $\checkmark$ \\
\hline GB091 & Lloyds Banking Group & GB & 7 & $\mathrm{x}$ & $\mathrm{x}$ & $\mathrm{x}$ & $\mathrm{x}$ & $\mathrm{x}$ & $\mathrm{x}$ & $\mathrm{x}$ & $\checkmark$ \\
\hline
\end{tabular}

Table B.2: Sample Banks. This table provides a list of all banks that took part in at least one of the seven European Banking Authority (EBA) stress tests in the sample. The x symbol shows that EBA data is available. The $\checkmark$ symbol denotes a bank included in the final sample. I excluded banks with three or less EBA observations and the four Greek banks that have been subject to only the first two and last two stress tests. 


\section{Additional Tables}

\begin{tabular}{clccc}
\hline Bank Country & GIIPS Bank Name & Exposure to & EAD $(€ \mathbf{m})$ & EAD/E \\
\hline GR & EFG Eurobank Ergasias & GR & 53,005 & 47.0 \\
GR & Alpha Bank & GR & 46,171 & 18.1 \\
IT & Banca Monte Paschi Siena & IT & 205,347 & 15.6 \\
ES & Banco Popular Espanol & ES & 120,981 & 11.2 \\
IT & Banco Popolare & IT & 122,583 & 10.0 \\
ES & Caixa & ES & 259,731 & 8.7 \\
IE & Irish Life and Permanent & IE & 36,487 & 8.0 \\
ES & BBVA & ES & 378,707 & 7.3 \\
IT & Intesa Sanpaolo & IT & 418,126 & 6.8 \\
IT & Unicredit & IT & 382,176 & 5.4 \\
IE & Bank of Ireland & IE & 68,883 & 5.2 \\
GR & EFG Eurobank Ergasias & PL & 5,707 & 5.1 \\
IE & Bank of Ireland & GB & 64,743 & 4.9 \\
IE & Allied Irish Banks & IE & 85,923 & 4.6 \\
GR & EFG Eurobank Ergasias & RO & 4,552 & 4.0 \\
ES & Banco Santander & ES & 355,523 & 3.3 \\
GR & EFG Eurobank Ergasias & BG & 3,607 & 3.2 \\
ES & Banco Santander & GB & 292,735 & 2.7 \\
GR & EFG Eurobank Ergasias & DE & 2,801 & 2.5 \\
IT & Unicredit & DE & 151,948 & 2.1 \\
GR & Alpha Bank & CY & 4,848 & 1.9 \\
IE & Irish Life and Permanent & GB & 8,466 & 1.9 \\
IE & Allied Irish Banks & GB & 32,117 & 1.7 \\
GR & Alpha Bank & RO & 4,261 & 1.7 \\
GR & Alpha Bank & GB & 3,059 & 1.2 \\
IT & Unicredit & AT & 74,355 & 1.0 \\
\hline
\end{tabular}

Table C.1: December 2010 Exposures at Default. The December 2010 EBA Stress Test disclosed the Exposures at Default (EADs) of stressed banks. The results include exposures to institutions, corporate, and real estate (commercial and residential). According to EBA, "banks have been requested to provide full overview of their credit exposures as of 31 December 2010 [...]." The first and second column report the banks' country and name. The third column shows the country with respect to which the EAD is measured. The last two columns report the EAD and the ratio EAD/Equity respectively. The table ranks the EBA sample banks according to the $\mathrm{EAD} / \mathrm{E}$ ratio and shows the aforementioned statistics for the subsample of GIIPS banks that have a EAD/E ratio above 1. Highlighted rows correspond to exposure to domestic country credit risk. 


\section{Additional Plots}
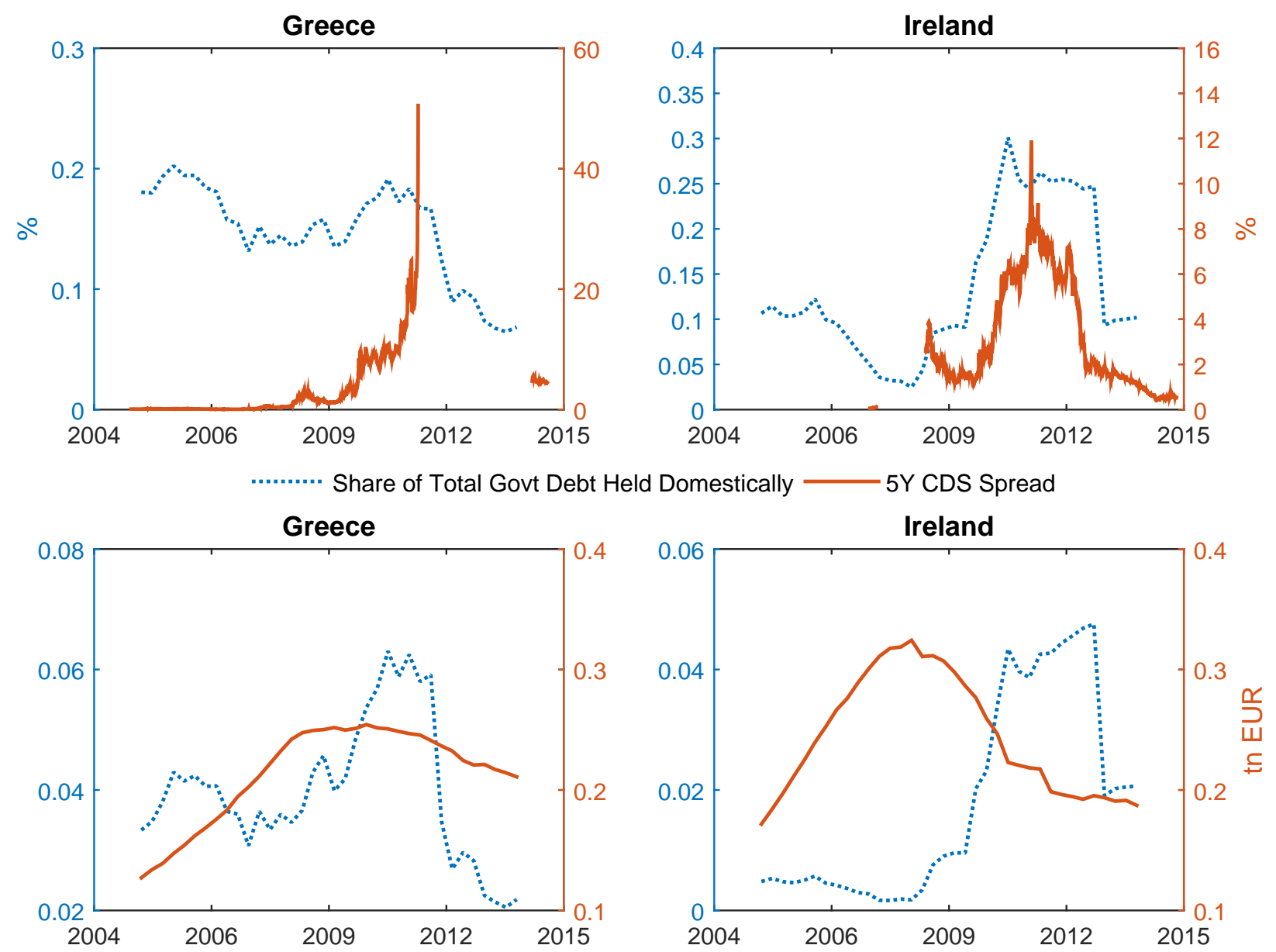

.......... Govt Debt Held Domestically (Quantity) — Credit To Non-Fin. Institutions

Figure D.1: Fact 1 and Fact 2 (Greece And Ireland). The top figure shows the share of sovereign debt owned by domestic banks (solid orange line, primary axis, (\%)) and the 5-Year USD denominated sovereign CDS spread (dotted blue line, secondary axis, (\%)) for Greece and Ireland. The bottom panel shows holdings of domestic government bonds by domestic banks (dotted blue line, primary axis, tn $€$ ) and domestic banks' credit to the non-financial private sector (solid orange line, secondary axis, tn $€$ ) for Greece and Ireland. Credit to non-financial entities includes credit to non-financial corporations (both private-owned and public-owned), households, and non-profit institutions. Credit is mainly in form of loans and debt securities. CDS spreads are from Bloomberg, data on credit to non-financial entities is from the Bank for International Settlements (BIS), and government debt ownership data is from Arslanalp and Tsuda (2012). 



\section{Index of Working Papers:}

\begin{tabular}{|c|c|c|c|}
\hline $\begin{array}{l}\text { February 16, } \\
2009\end{array}$ & $\begin{array}{l}\text { Burkhard Raunig, } \\
\text { Martin Scheicher }\end{array}$ & 152 & $\begin{array}{l}\text { Are Banks Different? Evidence from the } \\
\text { CDS Market }\end{array}$ \\
\hline $\begin{array}{l}\text { March 11, } \\
2009\end{array}$ & $\begin{array}{l}\text { Markus Knell, } \\
\text { Alfred Stiglbauer }\end{array}$ & 153 & $\begin{array}{l}\text { The Impact of Reference Norms on Inflation } \\
\text { Persistence When Wages are Staggered }\end{array}$ \\
\hline May 14, 2009 & Tarek A. Hassan & 154 & $\begin{array}{l}\text { Country Size, Currency Unions, and } \\
\text { International Asset Returns }\end{array}$ \\
\hline May 14, 2009 & Anton Korinek & 155 & $\begin{array}{l}\text { Systemic Risk: Amplification Effects, } \\
\text { Externalities, and Policy Responses }\end{array}$ \\
\hline May 29, 2009 & Helmut Elsinger & 156 & $\begin{array}{l}\text { Financial Networks, Cross Holdings, and } \\
\text { Limited Liability }\end{array}$ \\
\hline July 20, 2009 & Simona Delle Chiaie & 157 & $\begin{array}{l}\text { The sensitivity of DSGE models' results to } \\
\text { data detrending }\end{array}$ \\
\hline $\begin{array}{l}\text { November 10, } \\
2009\end{array}$ & $\begin{array}{l}\text { Markus Knell } \\
\text { Helmut Stix }\end{array}$ & 158 & $\begin{array}{l}\text { Trust in Banks? } \\
\text { Evidence from normal times } \\
\text { and from times of crises }\end{array}$ \\
\hline $\begin{array}{l}\text { November 27, } \\
2009\end{array}$ & $\begin{array}{l}\text { Thomas Scheiber } \\
\text { Helmut Stix }\end{array}$ & 159 & $\begin{array}{l}\text { Euroization in Central, Eastern and South- } \\
\text { eastern Europe - New Evidence On Its } \\
\text { Extent and Some Evidence On Its Causes }\end{array}$ \\
\hline $\begin{array}{l}\text { January } 11, \\
2010\end{array}$ & $\begin{array}{l}\text { Jesús Crespo } \\
\text { Cuaresma } \\
\text { Martin Feldircher }\end{array}$ & 160 & $\begin{array}{l}\text { Spatial Filtering, Model Uncertainty and the } \\
\text { Speed of Income Convergence in Europe }\end{array}$ \\
\hline $\begin{array}{l}\text { March 29, } \\
2010\end{array}$ & Markus Knell & 161 & $\begin{array}{l}\text { Nominal and Real Wage Rigidities. } \\
\text { In Theory and in Europe }\end{array}$ \\
\hline May 31, 2010 & $\begin{array}{l}\text { Zeno Enders } \\
\text { Philip Jung } \\
\text { Gernot J. Müller }\end{array}$ & 162 & Has the Euro changed the Business Cycle? \\
\hline $\begin{array}{l}\text { August 25, } \\
2010\end{array}$ & $\begin{array}{l}\text { Marianna ervená } \\
\text { Martin Schneider }\end{array}$ & 163 & $\begin{array}{l}\text { Short-term forecasting GDP with a DSGE } \\
\text { model augmented by monthly indicators }\end{array}$ \\
\hline $\begin{array}{l}\text { September 8, } \\
2010\end{array}$ & $\begin{array}{l}\text { Sylvia Kaufmann } \\
\text { Johann Scharler }\end{array}$ & 164 & $\begin{array}{l}\text { Bank-Lending Standards, the Cost Channel } \\
\text { and Inflation Dynamics }\end{array}$ \\
\hline $\begin{array}{l}\text { September 15, } \\
2010\end{array}$ & Helmut Elsinger & 165 & $\begin{array}{l}\text { Independence Tests based on Symbolic } \\
\text { Dynamics }\end{array}$ \\
\hline
\end{tabular}




\begin{tabular}{|c|c|c|c|}
\hline $\begin{array}{l}\text { December 14, } \\
2010\end{array}$ & Claudia Kwapil & 166 & $\begin{array}{l}\text { Firms' Reactions to the Crisis and their } \\
\text { Consequences for the Labour Market. } \\
\text { Results of a Company Survey conducted in } \\
\text { Austria }\end{array}$ \\
\hline May 10,2011 & Helmut Stix & 167 & $\begin{array}{l}\text { Does the Broad Public Want to Consolidate } \\
\text { Public Debt? - The Role of Fairness and of } \\
\text { Policy Credibility }\end{array}$ \\
\hline May 11,2011 & $\begin{array}{l}\text { Burkhard Raunig, } \\
\text { Johann Scharler }\end{array}$ & 168 & $\begin{array}{l}\text { Stock Market Volatility, Consumption and } \\
\text { Investment; An Evaluation of the Uncertainty } \\
\text { Hypothesis Using Post-War U.S. Data }\end{array}$ \\
\hline May 23,2011 & Steffen Osterloh & 169 & $\begin{array}{l}\text { Can Regional Transfers Buy Public } \\
\text { Support? Evidence from EU Structural } \\
\text { Policy }\end{array}$ \\
\hline May 23,2011 & $\begin{array}{l}\text { Friederike Niepmann } \\
\text { Tim Schmidt-Eisenlohr }\end{array}$ & 170 & $\begin{array}{l}\text { Bank Bailouts, International Linkages and } \\
\text { Cooperation }\end{array}$ \\
\hline $\begin{array}{l}\text { September 1, } \\
2011\end{array}$ & $\begin{array}{l}\text { Jarko Fidrmuc, } \\
\text { Mariya Hake, } \\
\text { Helmut Stix }\end{array}$ & 171 & $\begin{array}{l}\text { Households' Foreign Currency Borrowing in } \\
\text { Central and Eastern Europe }\end{array}$ \\
\hline $\begin{array}{l}\text { September 9, } \\
2011\end{array}$ & $\begin{array}{l}\text { Jürgen Eichberger, } \\
\text { Klaus Rheinberger, } \\
\text { Martin Summer }\end{array}$ & 172 & Credit Risk in General Equilibrium \\
\hline $\begin{array}{l}\text { October 6, } \\
2011\end{array}$ & Peter Lindner & 173 & $\begin{array}{l}\text { Decomposition of Wealth and Income using } \\
\text { Micro Data from Austria }\end{array}$ \\
\hline $\begin{array}{l}\text { October 18, } \\
2011\end{array}$ & Stefan Kerbl & 174 & $\begin{array}{l}\text { Regulatory Medicine Against Financial } \\
\text { Market Instability: } \\
\text { What Helps And What Hurts? }\end{array}$ \\
\hline $\begin{array}{l}\text { December 31, } \\
2011\end{array}$ & $\begin{array}{l}\text { Konstantins Benkovskis } \\
\text { Julia Wörz }\end{array}$ & 175 & How Does Quality Impact on Import Prices? \\
\hline $\begin{array}{l}\text { January 17, } \\
2012\end{array}$ & Nicolás Albacete & 176 & $\begin{array}{l}\text { Multiple Imputation in the Austrian } \\
\text { Household Survey on Housing Wealth }\end{array}$ \\
\hline $\begin{array}{l}\text { January } 27, \\
2012\end{array}$ & $\begin{array}{l}\text { Gerhard Fenz, } \\
\text { Lukas Reiss, } \\
\text { Martin Schneider }\end{array}$ & 177 & $\begin{array}{l}\text { A structural interpretation of the impact of } \\
\text { the great recession on the Austrian } \\
\text { economy using an estimated DSGE model }\end{array}$ \\
\hline $\begin{array}{l}\text { July } 27 \\
2012\end{array}$ & Helmut Stix & 178 & $\begin{array}{l}\text { Why Do People Save in Cash? Distrust, } \\
\text { Memories of Banking Crises, Weak } \\
\text { Institutions and Dollarization }\end{array}$ \\
\hline
\end{tabular}




\begin{tabular}{|c|c|c|c|}
\hline $\begin{array}{l}\text { August 20, } \\
2012\end{array}$ & Markus Knell & 179 & $\begin{array}{l}\text { Increasing Life Expectancy and Pay-As- } \\
\text { You-Go Pension Systems }\end{array}$ \\
\hline $\begin{array}{l}\text { September 25, } \\
2012\end{array}$ & $\begin{array}{l}\text { Fabio Rumler, } \\
\text { Walter Waschiczek }\end{array}$ & 180 & $\begin{array}{l}\text { Have Changes in the Financial Structure } \\
\text { Affected Bank Protability? Evidence for } \\
\text { Austria }\end{array}$ \\
\hline $\begin{array}{l}\text { November 9, } \\
2012\end{array}$ & $\begin{array}{l}\text { Elisabeth Beckmann, } \\
\text { Jarko Fidrmuc, } \\
\text { Helmut Stix }\end{array}$ & 181 & $\begin{array}{l}\text { Foreign Currency Loans and Loan Arrears } \\
\text { of Households in Central and Eastern } \\
\text { Europe }\end{array}$ \\
\hline $\begin{array}{l}\text { June 10, } \\
2013\end{array}$ & Luca Fornaro & 182 & International Debt Deleveraging \\
\hline $\begin{array}{l}\text { June 10, } \\
2013\end{array}$ & $\begin{array}{l}\text { Jenny Simon, } \\
\text { Justin Valasek }\end{array}$ & 183 & $\begin{array}{l}\text { Efficient Fiscal Spending by Supranational } \\
\text { Unions }\end{array}$ \\
\hline $\begin{array}{l}\text { July 24, } \\
2013\end{array}$ & $\begin{array}{l}\text { Thomas Breuer, Hans- } \\
\text { Joachim Vollbrecht, } \\
\text { Martin Summer }\end{array}$ & 184 & $\begin{array}{l}\text { Endogenous Leverage and Asset Pricing in } \\
\text { Double Auctions }\end{array}$ \\
\hline $\begin{array}{l}\text { September 23, } \\
2013\end{array}$ & Martin Feldkircher & 185 & A Global Macro Model for Emerging Europe \\
\hline $\begin{array}{l}\text { September 25, } \\
2013\end{array}$ & $\begin{array}{l}\text { Martin Gächter, } \\
\text { Aleksandra Riedl }\end{array}$ & 186 & $\begin{array}{l}\text { One Money, One Cycle? The EMU } \\
\text { Experience }\end{array}$ \\
\hline $\begin{array}{l}\text { December 9, } \\
2013\end{array}$ & $\begin{array}{l}\text { Stefan Niemann, } \\
\text { Paul Pichler }\end{array}$ & 187 & Collateral, Liquidity and Debt Sustainability \\
\hline $\begin{array}{l}\text { March 6, } \\
2014\end{array}$ & $\begin{array}{l}\text { Elisabeth Beckmann, } \\
\text { Helmut Stix }\end{array}$ & 188 & $\begin{array}{l}\text { Foreign currency borrowing and knowledge } \\
\text { about exchange rate risk }\end{array}$ \\
\hline $\begin{array}{l}\text { March 10, } \\
2014\end{array}$ & $\begin{array}{l}\text { Jesús Crespo } \\
\text { Cuaresma, } \\
\text { Martin Feldkircher, } \\
\text { Florian Huber }\end{array}$ & 189 & $\begin{array}{l}\text { Forecasting with Bayesian Global Vector } \\
\text { Autoregressive Models: } \\
\text { A Comparison of Priors }\end{array}$ \\
\hline $\begin{array}{l}\text { May 12, } \\
2014\end{array}$ & Claudia Steinwender & 190 & $\begin{array}{l}\text { Information Frictions and the Law of One } \\
\text { Price: "When the States and the Kingdom } \\
\text { became United" }\end{array}$ \\
\hline $\begin{array}{l}\text { May 12, } \\
2014\end{array}$ & Saleem A. Bahaj & 191 & $\begin{array}{l}\text { Systemic Sovereign Risk: Macroeconomic } \\
\text { Implications in the Euro Area }\end{array}$ \\
\hline
\end{tabular}




\begin{tabular}{|c|c|c|c|}
\hline $\begin{array}{l}\text { May 16, } \\
2014\end{array}$ & $\begin{array}{l}\text { John Bagnall, } \\
\text { David Bounie, } \\
\text { Kim P. Huynh, } \\
\text { Anneke Kosse, } \\
\text { Tobias Schmidt, } \\
\text { Scott Schuh and } \\
\text { Helmut Stix }\end{array}$ & 192 & $\begin{array}{l}\text { Consumer Cash Usage: A Cross-Country } \\
\text { Comparison with Payment Diary Survey } \\
\text { Data }\end{array}$ \\
\hline $\begin{array}{l}\text { May 19, } \\
2014\end{array}$ & $\begin{array}{l}\text { Konstantins Benkovskis } \\
\text { Julia Wörz }\end{array}$ & 193 & $\begin{array}{l}\text { "Made in China" - How Does it Affect } \\
\text { Measures of Competitiveness? }\end{array}$ \\
\hline $\begin{array}{l}\text { June 25, } \\
2014\end{array}$ & $\begin{array}{l}\text { Burkhard Raunig, } \\
\text { Johann Scharler and } \\
\text { Friedrich Sindermann }\end{array}$ & 194 & Do Banks Lend Less in Uncertain Times? \\
\hline $\begin{array}{l}\text { July } 28 \\
2014\end{array}$ & $\begin{array}{l}\text { Martin Feldkircher and } \\
\text { Florian Huber }\end{array}$ & 195 & $\begin{array}{l}\text { The International Transmission of U.S. } \\
\text { Structural Shocks - Evidence from Global } \\
\text { Vector Autoregressions }\end{array}$ \\
\hline $\begin{array}{l}\text { September 16, } \\
2014\end{array}$ & $\begin{array}{l}\text { Kim P. Huynh, } \\
\text { Philipp Schmidt- } \\
\text { Dengler, } \\
\text { Helmut Stix }\end{array}$ & 196 & $\begin{array}{l}\text { The Role of Card Acceptance in the } \\
\text { Transaction; Demand for Money }\end{array}$ \\
\hline $\begin{array}{l}\text { October 10, } \\
2014\end{array}$ & $\begin{array}{l}\text { Martin Brown, } \\
\text { Helmut Stix }\end{array}$ & 197 & $\begin{array}{l}\text { The Euroization of Bank Deposits in Eastern } \\
\text { Europe }\end{array}$ \\
\hline $\begin{array}{l}\text { October } 17, \\
2014\end{array}$ & $\begin{array}{l}\text { Ludmila Fadejeva, } \\
\text { Martin Feldkircher, } \\
\text { Thomas Reininger }\end{array}$ & 198 & $\begin{array}{l}\text { Spillovers from Euro Area and U.S. Credit } \\
\text { and Demand Shocks: Comparing Emerging } \\
\text { Europe on the Basis of a GVAR Model }\end{array}$ \\
\hline $\begin{array}{l}\text { December 18, } \\
2014\end{array}$ & Esther Segalla & 199 & $\begin{array}{l}\text { Shock Transmission through International } \\
\text { Banks: Austria }\end{array}$ \\
\hline $\begin{array}{l}\text { March 5, } \\
2015\end{array}$ & $\begin{array}{l}\text { Jonas Dovern, } \\
\text { Martin Feldkircher, } \\
\text { Florian Huber }\end{array}$ & 200 & $\begin{array}{l}\text { Does Joint Modelling of the World Economy } \\
\text { Pay Off? Evaluating Global Forecasts from a } \\
\text { Bayesian GVAR }\end{array}$ \\
\hline $\begin{array}{l}\text { May 19, } \\
2015\end{array}$ & Markus Knell & 201 & $\begin{array}{l}\text { The Return on Social Security with } \\
\text { Increasing Longevity }\end{array}$ \\
\hline $\begin{array}{l}\text { June 15, } \\
2015\end{array}$ & Anil Ari & 202 & Sovereign Risk and Bank Risk-Taking \\
\hline $\begin{array}{l}\text { June 15, } \\
2015\end{array}$ & Matteo Crosignani & 203 & $\begin{array}{l}\text { Why Are Banks Not Recapitalized During } \\
\text { Crises? }\end{array}$ \\
\hline
\end{tabular}




\section{Call for Entries: Visiting Research Program}

The Oesterreichische Nationalbank (OeNB) invites applications from external researchers for participation in a Visiting Research Program established by the OeNB's Economic Analysis and Research Department. The purpose of this program is to enhance cooperation with members of academic and research institutions (preferably post-doc) who work in the fields of macroeconomics, international economics or financial economics and/or with a regional focus on Central, Eastern and Southeastern Europe.

The OeNB offers a stimulating and professional research environment in close proximity to the policymaking process. Visiting researchers are expected to collaborate with the OeNB's research staff on a prespecified topic and to participate actively in the department's internal seminars and other research activities. They are provided with accommodation on demand and have, as a rule, access to the department's data and computer resources and to research assistance. Their research output will be published in one of the department's publication outlets or as an OeNB Working Paper. Research visits should ideally last between 3 and 6 months, but timing is flexible.

Applications (in English) should include

- a curriculum vitae,

- a research proposal that motivates and clearly describes the envisaged research project,

- an indication of the period envisaged for the research stay, and

- information on previous scientific work.

Applications for 2015 should be e-mailed to eva.gehringer-wasserbauer@oenb.at by November 1, 2015.

Applicants will be notified of the jury's decision by mid-December. The following round of applications will close on May 1, 2016. 